\title{
Social citizenship and people with dementia: Designing social care policies in Sweden
}

\author{
Jonas Nordh
}

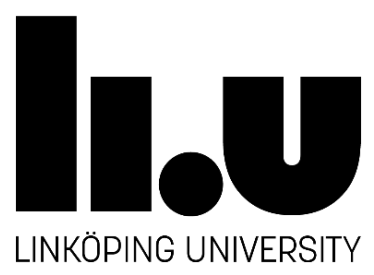

Linköping Studies in Arts and Science No. 696

Department of Social and Welfare Studies

National Institute for the Study of Ageing and Later life [NISAL]

Center for Dementia Research [CEDER]

Norrköping 2016 
Linköping Studies in Arts and Science • No. 696

Social Citizenship and people with dementia: Designing social care policies in Sweden

Jonas Nordh

Distributed by:

Department of Social and Welfare Studies

National Institute for the Study of Ageing and Later Life

Linköping University

60174 Norrköping

C)Jonas Nordh, 2016

Department of Social and Welfare Studies

Cover picture/Design: Andreas Thorén

Published article has been reprinted with the permission of the copyright holder.

Printed in Sweden by LiU-Tryck, Linköping, Sweden, 2016

ISBN 978-91-7685-676-5

ISSN0282-9800 


\section{ABSTRACT}

People with dementia are commonly in need of some form of social care from the social services in order to manage their everyday situations. However, social services are shaped by the construction of policy targets, i.e. the construction of people with dementia as citizens. The aim of this dissertation is to explore the social citizenship of people with dementia. Social citizenship for people with dementia is explored by studying how people with dementia have, in policy documents, been constructed as a target group, and also by studying how policies are enacted in practice by care managers, in their work and in their meetings with people with dementia.

This is illustrated by studying policy documents from national level which range over nearly 40 years. It is shown that, if and when people with dementia are visible in policy documents, they commonly have a negative construction based on their cognitive and communicative abilities, and they are constructed as a burden, disturbing and incapable, wherein focus lies in their negative attributes. We further investigate in this dissertation, how street-level bureaucrats, in this case care managers, experience meeting with people with dementia when they apply for social services. This part of the dissertation is built upon 19 interviews with care managers from four different organisations, which show that care managers experience difficulties in their meetings with people with dementia. These difficulties comprise the exchange of information between care managers and people with dementia, refusal of social services by the person with dementia, the influence of relatives and other professions as well as moral dilemmas, such as the relations between the person with dementia and their relatives. The study also shows that care managers have little support from policies, e.g. legislation and guidelines, in how to handle these dilemmas, and must thus create their own local ways of handling these situations. This requires that care managers are influential policy actors concerning the policy target group of people with dementia.

The policy processes which this dissertation illustrates, affect the social citizenship of people with dementia. It is shown that they, to an extent, have difficulties in influencing their own everyday situation concerning social services. Finally, the policy processes, such as the construction of people with dementia as well as the policy practice in which they encounter care managers, will affect their possibility to influence their social citizenship.

Keywords: Social citizenship, people with dementia, policy, policy practice, policy actors, street-level bureaucrats, social work, care managers, rights 
Personer med demenssjukdom behöver vanligtvis någon form av socialt stöd från socialtjänsten för att kunna hantera sin egen vardag. Emellertid så är socialt stöd format av konstruktionen av policymålgrupper, dvs konstruktionen av personer med demenssjukdom som medborgare. Syftet med denna avhandling är att undersöka det sociala medborgarskapet för personer med demenssjukdom genom att studera hur dessa personer, som målgrupp och som socialt problem, har konstruerats i policydokument. Syftet är vidare att studera hur policys överförs i praktiken av biståndshandläggare inom socialtjänsten, i deras arbete och i deras möten med personer med demenssjukdom.

Detta belyses genom studier policydokument på nationell nivå som spänner över nästan 40 år. Det visas att om och när personer med demenssjukdom är synliga i policydokument så har de vanligtvis en negativ konstruktion som baseras på deras kognitiva- och kommunikativa förmågor och de är konstruerade som betungande, störande och inkapabla där fokus läggs på deras negativa egenskaper. Vidare undersöks i denna avhandling även gräsrotsbyråkrater, i denna avhandling biståndshandläggare, och hur de upplever mötet med personer med demenssjukdom då de ansöker om socialt stöd från socialtjänsten. Den delen av avhandlingen bygger på 19 intervjuer med biståndshandläggare från fyra olika organisationer och visar att biståndshandläggare upplever svårigheter i deras möten med personer med demenssjukdom. Dessa svårigheter ligger i utbytet av information mellan handläggare och personen med demens, vägran från personen med demens att ta emot stöd, inflytande från anhöriga och andra professioner samt moraliska dilemman som relationen mellan personen med demenssjukdom och anhöriga. Studien visar också att biståndshandläggare har lite stöd från policys, såsom lagar och riktlinjer, i hur de ska hantera dessa svårigheter och måste således hitta egna, lokala, sätt att hantera dessa situationer. Det innebär att handläggare är inflytelserika policyaktörer rörande policymålgruppen personer med demenssjukdom.

De policyprocesser som avhandlingen berör påverkar det sociala medborgarskapet för personer med demenssjukdom. I denna avhandling visas det att de, till viss del, har svårigheter att påverka sin egen vardag i förhållande till stöd från socialtjänsten. Slutligen påverkar policyprocesser, så som konstruktionen av personer med demens samt i policypraktiken där de möter handläggare, möjligheten för personer med demens att påverka sitt sociala medborgarskap.

Nyckelord: Socialt medborgarskap, personer med demenssjukdom, policy, policypraktik, gräsrotsbyråkrater, socialt arbete, biståndshandläggare 


\section{CONTENTS}

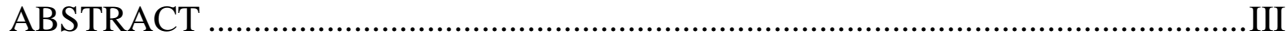

ACKNOWLEDGMENTS .............................................................................. VII

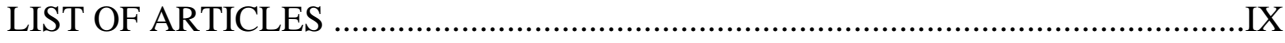

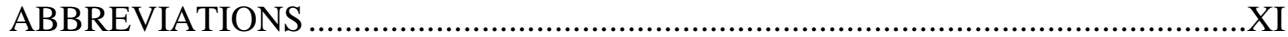

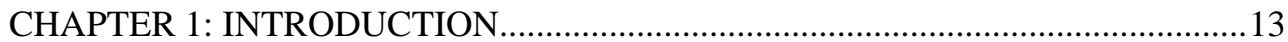

Formulation of a problem: People with dementia encountering the Swedish welfare system ..................................................................................13

Previous research on people living with dementia ..........................................17

Aim and research questions ..............................................................................24

The structure of the dissertation..........................................................................25

CHAPTER 2: THE SWEDISH SOCIAL POLICY SETTING.....................................27

The organisation of social services in Sweden...................................................27

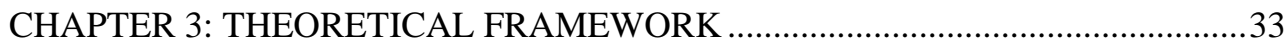

Introduction to theoretical framework ..................................................................33

Social citizenship and social rights ....................................................................33

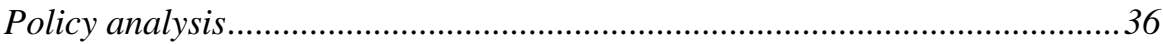

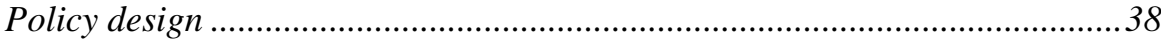

Summary of theoretical framework ..................................................................46

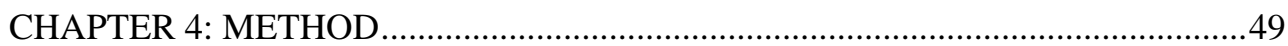

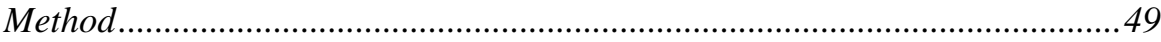

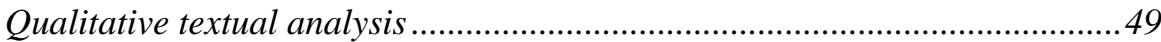

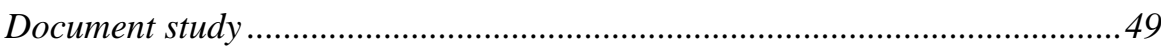

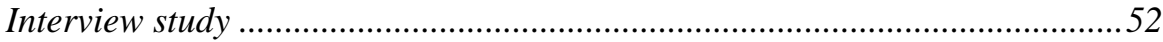

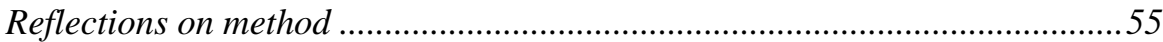

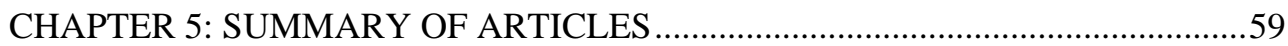

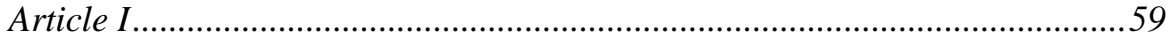

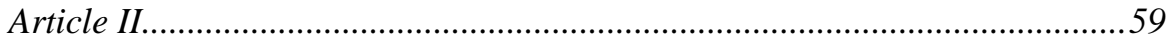




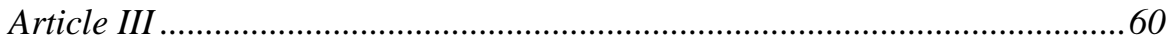

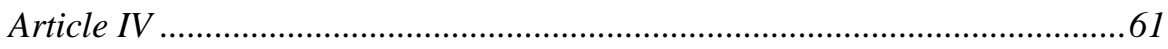

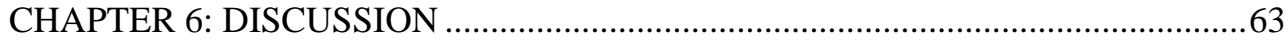

People with dementia as full citizens? ..........................................................63

People with dementia as stereotyped and stigmatised - A negative

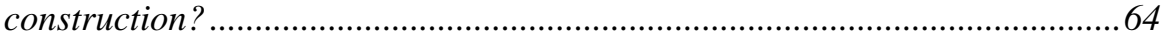

Lack of policies and guidelines - Implications for social citizenship? ............66

Policies in specific situations - Tensions in care-management .......................68

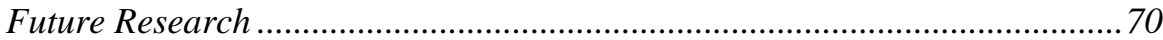

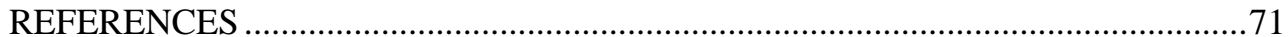

Appendix 1 - Topic Guide 


\section{ACKNOWLEDGMENTS}

There are many people to thank for contributing, in various ways, to this dissertation. I would start off by thanking my main supervisor Lars-Christer Hydén. Thank you for your support throughout this time and for guiding me forward in the process of finishing this dissertation. I would also like to thank my cosupervisors, Ann-Charlotte Nedlund for first of all being each other's co-authors as well as you being a terrific colleague in the project on citizenship and people with dementia. Secondly, I would also thank you for your support and guidance throughout the whole $\mathrm{PhD}$ process, both regarding the thesis, the surrounding work and issues outside of work. Marie Jansson for thoughtful comments on my dissertation but also for reminding me to be organised and structured and that the $\mathrm{PhD}$ project is not all that matters. I want to direct a special thanks to all three of you for making me pull through this last year of my PhD-project. Thank you!

I would also like to thank the persons that have helped me forward by reading my manuscripts and for giving me valuable comments on how to proceed with my dissertation. Thank you, Stig Montin for your feedback on my synthesis chapter as well as my articles during my final seminar. Thanks also to Sabine Gruber and Mikael Rundqvist many good comments. I would also like to thank Magnus Dahlstedt for your suggestions in my 60-percent seminar and also Annika Taghizadeh Larsson and Martin Börjesson for your comments. You have all had a part in guiding my $\mathrm{PhD}$ project forward.

Thanks to all the colleagues at CEDER, NISAL and the Division for Health and Society who have supported me in my work by reading drafts and inviting for interesting discussion at seminars and in the fika room. I want to direct a special thanks to all the PhD-students at these departments for making it an enjoyable time during my $\mathrm{PhD}$ project. A special thanks to Johannes and Lisa for the time that we shared an office

I also want to thank the organisations in the municipalities in which I have made the interviews for this research, for having the time and the willingness to participate in this research project.

Last but not least I want to thank my family and friends for your support even though some of you still do not know what I am actually doing. My mother Monica and my father Stefan for always being there and for supporting me in all kinds of ways and in all endeavours. My sisters Åsa and Malin for being my big sisters with all what that entails. My oldest friends Robin, Daniel, Chistoffer, Petter, Eddie, Johan, Benny, and Isac for all the things, both good and not so good, we have done together over the years, and still are doing. My, not that old but, very good friends Brolle, Rydha, Kvalle Clas, Skalman, Bengt etc. (too many too 
count) for being team mates, matklubbs participants and traveling buddies these last years. And to all which I have not forgotten but not mentioned by name, thank you for having been, or still is, a part of my life.

Linköping, September 2016

Jonas Nordh 


\section{LIST OF ARTICLES}

I. Ann-Charlotte Nedlund \& Jonas Nordh. (2015). Crafting citizen(ship) for people with dementia: How policy narratives at national level in Sweden informed politics of time from 1975 to 2013. Journal of Aging Studies.34, 123-133.

II. Ann-Charlotte Nedlund \& Jonas Nordh. (Submitted). Constructing citizenship targets: A matter of labelling, imaging and underlying rationales in the case of people with dementia.

III. Jonas Nordh \& Ann-Charlotte Nedlund. (Submitted). Policy in practice or policy on paper: Care managers as creative street-level bureaucrats when handling legislation and policies concerning people with dementia.

IV. Jonas Nordh \& Ann-Charlotte Nedlund. (2016). To co-ordinate information in practice: Dilemmas and strategies in care management for citizens with dementia. Journal of Social Services Research. 1-17. 


\section{ABBREVIATIONS}

NBHW National Board of Health and Welfare [in Swedish : Socialstyrelsen]

SALAR Swedish Association of Local Authorities and Regions [in Swedish : Sveriges Kommuner och Landsting]

SSA Social Services Act [in Swedish : Socialtjänstlagen]

ASS Act concerning Support and Service for Persons with Certain Functional Impairments [in Swedish : Lagen om Stöd och Service för vissa Funktionshindrade] 


\section{CHAPTER 1: INTRODUCTION}

People with dementia have, since their emergence, in the public debate been given more and more attention. However, only nine percent of those estimated to have a dementia diagnoses have a medical diagnosis, which shows the low status of this target group (NBHW, 2014). People with dementia have not succeeded in making their voice heard to the same extent as other policy target groups such as people with disabilities concerning their rights as citizens within the welfare system. This may be due to the fact that people with dementia have been principally described from a medical perspective which emphasise their cognitive and communicative dysfunction. The focus has mostly been on the inabilities they have been ascribed, the element of not being able to make their voice heard, both in social as well as in political contexts. In order for persons with dementia to influence their own situation as well as their social citizenship, it is important that persons with dementia have the opportunity to assert their voice in different political and social forums. In this thesis, it is the possibilities of social citizenship and social rights for people with dementia that will be in focus, problematized and discussed.

\section{Formulation of a problem: People with dementia encountering the Swedish welfare system}

Harold Lasswell (1936) summarised politics into a classic question of who gets what, when and how? This question captures politics in its essence since politics is about the allocation of limited public resources. However, the allocation of resources entails behaviour and ideas that are closely connected to the authoritative distribution of public values (Lundquist, 2010; 1998).

Social citizenship entails allocation of resources and boils down to what support or restrictions that should be afforded and which target groups of citizens that are entitled to support (Soss, 2005). Soss et al. (2011) argues that the sphere of welfare policies is influenced by several factors such as ideological concerns, outcomes of elections, social controls, policy innovations and that it also is a forum for moral problem solving as it commonly revolves around the equality between citizens. Social services is thus an interesting policy area to study since it is changing due to several factors. Social citizenship is commonly referred to as the social rights of citizens. This entail universal governmental incentives such as education and pensions which are given to all citizens regardless of their needs but also support for citizens that is needs-based (Rothstein, 2010a), meaning that support is assessed and provided according to the citizens need, for example home care services for older person. In Sweden the social rights are universal 
(Rothstein, 2010a), and all citizens could thus be assessed for support regardless of e.g. gender, social and economic class as long as their needs meet the criteria for social support for that specific policy target group. The content of citizenship entails not only what citizens are entitled to in the form of rights stipulated in legislation but also substantive rights (Rothstein, 2010a), what the citizens actually get, in terms of e.g. social services, when encountering the welfare system. Some social services, such as economic support, unemployment insurance, elderly care and disability support are targeted at specific categories of citizens, and citizens can, by belonging to a specific category, be granted specific services aimed at that target group. As such social services in Sweden can differ if you belong to, for example, people with disabilities or older people, above the age of 65 (SFS 2001:453; SFS 1993:387). Social rights, in contrast to political and civil rights, are not as constitutionally rooted in legislation and are thus subject to change (Dwyer, 2010). The allocation of resources and also how this allocation manifests itself can vary between different categories of citizens and also change through time depending on the political climate but more importantly by the actors who influence the policies (Considine, 2005). The social rights and the allocation of resources is thus a process in which specific target groups are marginalised, de-marginalised, constructed or re-constructed (Daly, 2011; Rodger, 2000). But what happens when certain groups do not have the power, or the capabilities, either personally or through representatives, to make themselves heard in politics where the allocation of resources are decided? At least three different issues can be discerned.

First, people with dementia as a target group. The allocation of public resources is a dynamic process in which it is decided which social rights citizens will enjoy and also which citizens will receive them (Isin \& Wood, 1999). Which categories of citizens that are entitled to social rights is a struggle and depends on the actors involved in the discussion regarding the allocation of public resources. Actors try to influence the political argumentation for the incentives given to specific groups of citizens and this is done by a wide range of actors, e.g. politicians, public officials, political advisors, NGO's, civil associations and citizens themselves, and in different forums, e.g. the public debate, the statelevel, local authorities, public administration (Howlett, 2015). This struggle entails the discerning of undeserving and deserving groups of citizens and also the support to which they are entitled to (Schneider \& Ingram, 1997; 1993). How social problems, as well as their solutions, are formulated along with how citizens are constructed as targets influences policy action and the incentives, e.g. social services, that citizens can enjoy (Schneider et al., 2014; Schneider \& Ingram 2005; 1997). Public policies are ways that governments institutionalise, change and legitimise social constructions of citizens (Schneider \& Ingram, 1993; Hajer, 1993). What citizens then actually receive in the form of social support is based on the policy target group in which they are categorised. People with dementia in Sweden, in relation to the social services system, are not de- 
fined as a specific target group but rather belong to other target groups, mainly those of older people and people with disabilities. People living with dementia are not given, in legislation, Social Services Act (SSA) (SFS 2001:453), Act concerning Support and Service for Persons with Certain Functional Impairments (ASS) (SFS 1993:387) and Instrument of Government (SFS1974:109), explicit attention as a target group but are covered by being categorised into other target groups, notably older people and people with disabilities.

Second, the risk of negative ascriptions. People with dementia, similar to how other target groups such as people with disabilities (Oliver, 2009; Priestley, 2003) or older people (Jönson, 2009; 2002; Nelson, 2002), previously have been discerned and elevated to the public debate, so too have people with dementia recently become the object of public debate. Since categories of citizens are constructed (Schneider \& Ingram, 2005; 1997), the discerning of specific groups also comes with a simplistic construction of target groups which often tend to homogenise and stereotype specific groups of citizens (Stone, 2012). Even though the discerning of target groups as social problems may include them in society as well as strengthening their citizenship rights it also risks to marginalising and stigmatising them since it often comes with negative constructions which are difficult to change. Even though groups such as older persons have, since the 1970s, received more attention in the public debate, emphasising the neglect of aging as well as how to properly handle this target group, it has been hard to reconceptualise the meaning and images of old age both politically and in research (Jönson, 2002; Nelson; 2002; Bytheway, 1995). The categorisation as well the constructions of categories are thus difficult to change. The enjoyment of social rights often refers to a rejection of certain capabilities in order to receive social services and thus the advocacy for certain rights may depict groups of citizens as unequal. Oliver et al., (2012) and Oliver (2009) argue that perception of specific categories is important in the provision of social services and where people with disabilities are concerned, they have struggled to not be depicted only as a category deserving of welfare but also as active citizens the same as any other citizen. However, people living with dementia have been, and still are, negatively constructed and are ascribed negative attributes (Behuniak, 2011) compared to, for example, people with disabilities and cancer patients. This is apparent in the public debate, media (c.f. DN, 20160804) as well as policy (Boyle, 2010; Baldwin, 2008) and the negative construction will thus affect their social citizenship and how the allocation of resources targeted at this group will manifest itself.

Third, the possibilities for people with dementia of voicing and claiming rights. The content of citizenship does not only entail which rights citizens receive but also how they are able to influence the processes in which these rights are formed (Isin \& Turner, 2007). Bellamy (2001) argues that citizenship is not only about receiving rights but also being able to claim those rights as well as having the possibility to influence the forming of those rights. This involves not only the possibility to influence the formation of legislation, policies and guide- 
lines, but also the situations in which policy is practiced. Citizens can influence the forming of rights in several ways, by voting, by advocacy but also by bringing new cases to the government institutions that present new situations which have to be considered (Bellamy, 2008; 2001; Wagenaar \& Cook, 2003). In order to be granted social services, citizens have to apply for them, and then their needs are assessed (Lindelöf \& Rönnbäck, 2007) in meetings with street-level bureaucrats (Lipsky, 1980) who are the public officials, i.e. care managers, the citizens meet in their encounter with the welfare system. Street-level bureaucrats are highly influential in the provision of social services since their knowledge and attitude towards the target group affect their way of handling specific situations (Brodkin, 2015; 2011; Maynard-Moody \& Musheno, 2000) and their routines and practices (Nedlund, 2012) will influence the policy area of social services. Assessments on social services are also a negotiation between citizens and care managers (Scourfield, 2015; Olaison \& Cedersund, 2006) and how this negotiation plays out will likewise affect the substantive rights of the citizens. Accordingly, citizens need to be able to be active agents, both in forming policies as well as in the meetings with the welfare system, in order to be able to assert power over their own everyday situation.

So in conclusion, by returning to Lasswell's (1936) question we can see that who gets what, when and how, relies on how policy action is informed by the processes in which social problems and their solutions are constructed (Schneider \& Ingram, 2005; 1997). If people with dementia, as citizens, cannot influence the policy area and the construction of themselves as target groups, as well as experiencing difficulties in formulating their own voice when encountering the welfare system when meeting with care managers, it will be challenging to be able to influence their social citizenship (Bellamy, 2008). Policy processes permeate public administration and its different levels and it is central to understand these processes through analysis (Torgersen, 2015). To understand the allocation of public resources critically entails not only seeing policies as inputs and outputs but rather as processes that are informed and shaped by interests, values and normative assumptions, both political and social (Fischer et al., 2015; Barbehön et al., 2015). Further, this perspective on policies aims to identify aspects such as social justice (Fainstein, 2015).

Studying specific groups of people in relation to socials services may help shed light on the dynamic process of provision of welfare and also how social citizenship is constructed. People living with dementia serve an interesting case in regard to this challenge since they are a separate group at the same time as they also belong to other vulnerable groups, older people and people lacking mental capacity (Galpin, 2010). 


\section{Previous research on people living with dementia}

\section{People with dementia: A bio-medical perspective}

Before the introduction of the diagnosis Alzheimer's disease dementia was merely considered as a natural state of normal ageing. However, by the understanding of Alzheimer's disease and the connection to medicine, people with dementia have been confined to the research on the symptoms and behaviour results of having dementia (Ballenger, 2006). Previous research on dementia has mostly been through a bio-medical perspective focusing on the disease itself, its physical causes, its physical and cognitive consequences etc. but only to a small degree on how these actually affect the everyday life of people living with dementia. However, this sort of research is still ongoing today but was at the end of the twentieth century, accompanied by other perspective on dementia (Bartlett, 2014).

\section{People with dementia: From a medical perspective to personhood}

Even though the medical perspective is still strong within dementia research a shift from the medical perspective started with the concept of personhood (Kitwood, 1997). Personhood as explained by Kitwood (1997, 8), is a "status that is bestowed upon one human being, by others, in the context of relationship and social being. It implies recognition, respect and trust”. The personhood perspective also sheds light on the inter-subjectivity and the relationships in which people with dementia are engaged (Baldwin \& Capstick, 2007). Focus in this perspective has also been addressing the behaviour, performance, social contexts and personal history of the person and this approach has led to developments in care, e.g. person-centred care and developments in social policies concerning people living with dementia (O’Connor et al., 2007). However, the personhood perspective still emphasises individuals, although considered a person, the agency for people living with dementia is still in question since they are reliant on other actors and the potential political power of people living with dementia is neglected (Downs, 1997). Lately this concept has been challenged by people who have been criticising it, for not being able to see a person living with dementia as someone who has agency, or as a social actor within society (Bartlett \& O'Connor, 2010). The critic lies in the notion that the concept of personhood is seen as being too individualised and therefore exclusionary (Baldwin \& Greason, 2016; Baldwin \& Capstick, 2007). Even though the personhood perspective shifted towards a more inclusionary view of dementia the personhood perspective focused on health and psychological issues concerning dementia it did not properly problematise people with dementia in relation to political power and as actors concerning their everyday situation (Bartlett \& O’Connor, 2007).

There have in recent years been more and more studies on people living with dementia, their experience of their impairments, communicative abilities, chang- 
es in relations with people in their social surroundings, their agency, their identity, communicative abilities and so on (c.f. Hydén \& Hellström, 2016; Hellström et al., 2015; Hydén 2014; Plejert et al., 2014, Hydén \& Nilsson, 2013) which have moved beyond both the medical perspective as well as the personhood perspective of people living with dementia. Accordingly, research on people living with dementia has become more attentive to the fact that people living with dementia can be involved in social activities, as a participant in social environments and as political agents (Bartlett, 2014).

\section{People with dementia: The emergence of a citizenship perspective}

Studies regarding people living with dementia from a citizenship perspective have in recent years also gained more attention and a shift from both a medical perspective and from a personhood perspective have been promoted. Even though Barnes (2007) and Bambra et al. (2005) is pointing out that care is absent in the discourse of citizenship the citizenship perspective has been promoted in the discourse of care for people living with dementia (Bartlett \& O'Connor, 2010; 2007). The citizenship perspective entails that people living with dementia being considered as active and social citizens and not only confined to the discourse of medical perspectives, as people with less cognitive functions and thus not able to partake in social and political activities (Bartlett \& O'Connor, 2010). The consequences of a dementia diagnosis can in a worst case scenario lead to stigmatisation and dehumanisation of people living with dementia and the changes in the person's cognitive and communicative abilities can cause the exclusion of people living with dementia in, for example, social contexts. This can be, for instance, by constraints on others to interact with people living with dementia and members of the group have often been considered as passive actors. This can lead to what many define as social death. This is when people are considered incapable of social participation and thought of as dead when they are alive. Other metaphors that are being used concerning older people and those living with dementia are; a state between life and death, the living dead, death in slow motion, the almost dead and even zombies (Behuniak 2011; Brannelly 2011a; Matthews 2006). In contrast the citizenship perspectives promote people living with dementia as social active citizens focusing on other aspects other than those that come with a dementia diagnosis. These labels or epithets show that people who have a dementia diagnosis are constructed in a certain manner, as people who are not able to participate in social contexts or even worse, as people who are not worth including. 


\section{Dementia}

Dementia, in the new DSM-5 defined as neuro Major Neurocognitive Disorder, is defined as global disturbances of intellectual functions. Dementia is comprised of several diseases that share the same or similar cognitive symptoms. These symptoms are changes in prominently cognitive functions, such as memory (episodic and semantic), language and executive functions (planning).

Dementia is commonly divided into three groups depending on causes and course of events.

Neurodegenerative dementia diseases: These dementia diseases are caused by degenerative processes on a cellular level in the brain which affect both the nerve cell and the connections between nerve cells. These degenerative processes can start in different parts of the brain. Alzheimer's disease commonly start in hippocampus which affect functions in memory and Frontotemporal dementia in the frontal and the temporal lobes which affect social behaviour and linguistic understanding.

Vascular dementia: Due to vascular diseases the blood flow to and within the brain can fluctuate which may affect the functionality of the brain and cause decline in cognitive functions. Vascular diseases can affect parts of the brain or the whole brain. The symptoms of vascular dementia can vary depending on the affected part of the brain but common symptoms are changed functions in speech, mild memory problems, problems in planning and following certain steps.

Other types of dementia diseases: The symptoms can be caused by other types of neurological diseases such as Parkinson's, and Huntington. They can also be caused by virus diseases such as HIV infections and by prion diseases. In all cases of other types of dementia diseases, the brain is affected in a way that will deteriorate the cognitive functions.

Common for all dementia diseases, except alcohol related dementia, is that they are progressive and will eventually affect the whole brain and its functions. Today there are no known treatment for dementia except from some symptom alleviating medication. The knowledge about, especially neurodegenerative dementia is still limited even though there is extensive ongoing research.

(Marcusson et al., 2011)

Behuniak (2010) argues that the individualisation of the personhood lens is one of the reasons that the model has had little influence in the field of law. Bartlett \& O’Connor (2007) also criticise the personhood lens by arguing that it overlooks the dimension of power, both the power to position people living with dementia from outside the group but also for them to exert their own power. They therefore emphasise a change from a personhood lens to a citizenship lens. Gil- 
mour \& Brannelly (2009) also notes the power dimension regarding people living with dementia. They mean that this group is considered as subaltern which in this sense is described as disempowered and marginalised. The marginalisation and invisibility of this group is not only because of their inability to communicate but also the refusal of others to listen or to see them.

Bartlett \& O’Connor (2010) as well as Gilmour \& Brannelly (2009) argue for a citizenship approach in discussing people living with dementia rather than a personhood approach. Behuniak (2010) promotes that people living with dementia should be regarded as vulnerable persons. This is because, according to Behuniak (2010), the citizenship approach implies some kind of action, a citizen pays taxes, votes, mobilises, protests, donates money etc. It is therefore hard to integrate the different challenges that people living with dementia face into citizenship status. The equality in rights which citizenship promotes requires, according to Behuniak (2010), only that similarly situated people are given the same treatment. This is problematic because of the fact that citizens are different from each other. In this sense the citizenship approach is as exclusionary as the personhood approach. However, other studies have shown that people living with dementia can, and do, actively discuss their situation with different actors for example each other (Örulv, 2012), relatives (Hellström \& Torres, 2013) and care managers (Österholm, 2016). Studies have also shown that people living with dementia are capable of political actions such as claim-making of specific rights (Bartlett, 2014) highlighting that people with dementia can be, and in fact are, active citizens.

\section{People with dementia: A citizenship perspective}

Even though people living with dementia have been studied with a citizenship lens (c.f. Bartlett \& O’Connor, 2010; 2007; Gilmour \& Brannelly, 2009) the discussion on the decision making capacity of people living with dementia often ends up revolving around their care, leaving out a broader sense of citizenship aspects. Boyle (2008) looked at legislation concerning people with impaired mental health but this also ends up in the decision-making capacity of care and in discussing specific rights. Brannelly (2011b) argues that in promoting citizenship and the possibility to influencing their own situation can be achieved by using an "ethics of care" approach when discussing care for people living with dementia. Rights and responsibilities are incorporated in ethics of care and by adopting this approach citizenship can be sustained for people living with dementia since it covers the notions of autonomy, power, participation, equality and justice. Kelly \& Innes (2013) and Boyle (2010) promote a human rights approach to people living with dementia in order for them to facilitate their own citizenship. By adopting a human rights approach to dementia care nursing they argue that people living with dementia will be included, participate and have a role, and contin- 
ue to thrive in positive relationships. All of these studies, even though they promote some form of citizenship lens for problematizing the everyday lives of people living with dementia have ended up in micro-level issues such as care and not being able to recognise other aspects of citizenship such as participation, mobilisation and admission to contexts other than their need for health and social care and the possibility to influence that care.

However, there are some studies that go beyond the aspect of care for people living with dementia focusing on more societal issue concerning citizens with dementia. Craig (2004) maintains, in his article about citizenship and older persons, that there has to be a social inclusion for older people within the community in order for them to exert their citizenship. In order for this to be possible participation and social inclusion is important in all parts of society and not only in what care is given. There are some who have studied participation for older people and people living with dementia besides that of what care to get but they also tend to focus on a single issue, that of voting (McEldowney \& Teaster 2009), and ignore other forms of participation unnoticed. Tiraboschi et al. (2011) has also studied the voting participation of people living with dementia with a focus on the assessment of voting competence for people with dementia. However, citizenship and belonging to a society entails more than just being given the opportunity to vote, such as being able to be politically and socially active in the community in which they live. These studies also culminate with in assessing the cognitive functions of people living with dementia. Accordingly, people living with dementia are not considered as citizens like everyone else but rather as someone with disability. Bartlett (2014) has studied the experience of people living with dementia who are politically active in their community and concludes that this gives people living with dementia a reaffirmation of their citizenship identity because it (re)locates the individuals within a realm of work. However, the experience of these people is also that of feeling fatigue as well as oppression due to normative perceptions about their diagnosis. Even so, the study has shown that people living with dementia can be active social citizens and also highlights them as capable citizens.

Even though elements such as social rights concerning social care, health care, self-determination and decision-making regarding one's own everyday life are important aspects concerning citizenship studies, these elements have not been extensively studied within this field of research. Studies such as Hunter \& Doyle (2014) have shown how policies regarding dementia in Australia have been emerging with the help of dementia advocates who have influenced this policy issue to become recognised and politicised as a legitimate policy issue. The study shows that by having influential advocacy the issue of dementia have been differentiated from the group of older people in general.

Bartlett (2016) argues that the citizenship perspective has yet to play an important role in dementia studies regarding different aspects such as policy development, care encounters and dementia friendly communities. Brannelly (2016) 
discerns three relationships between people with dementia and citizenship which are citizenship in relation to the state, citizenship as practice and citizenship as identity and belonging. Sonnicksen (2016) has problematized the relationship between people with dementia, democracy and full citizenship and concludes that there are challenges and implications for promoting full citizenship in regards to democracy concerning people with dementia. Clarke \& Bailey (2016) have studied people with dementia through narrative citizenship and explore how people with dementia can display their understanding, and also influence others, concerning the view of dementia. Studies that emphasise citizenship as practice, i.e. citizenship realised in relationship and through action (c.f. Sonnicksen, 2016; Österholm \& Hydén, 2014; Bartlett, 2014) is further supported by Baldwin \& Greason (2016) which introduces the concepts of midi- and micro citizenship to dementia studies. Nedlund \& Taghizadeh Larsson (2016) and Boyle (2014) have studied citizenship in regards to self-determination and decision-making in institutional and legal contexts and outline practical implications concerning these issues regarding people with dementia.

\section{People living with dementia in Sweden}

The number of people with dementia in Sweden are estimated to 113000 169000 . The estimated number is due to that all people with dementia do not receive a proper diagnosis. It is not certain that the number of people with dementia will increase coming years since studies have shown tendencies for an increase as well as a decrease.

Unclear estimations on the prevalence of dementia also give estimated societal cost for dementia. In Sweden the societal cost for formal care for people with dementia is estimated to 54 billion - 65 billion (SEK). Of the formal care the municipalities are responsible for 78 percent of the total national budget for taking care of people with dementia. The informal care is estimated at 7,6 million 71,5 billion (SEK). Compared to the treatment and care of patients with the ten most common cancer diseases, 4,9 Billion SEK, the cost for care of people with dementia is very high.

It is important to emphasise that these numbers are estimations which gives an indication of the situation concerning people with dementia in Sweden.

(National Board of Health and Welfare, 2014a, 2014b)

Although the citizenship perspective concerning people with dementia is a new enterprise it has had growing influence in dementia studies over the past years and will further help the debate regarding people with dementia as citizens as well as problematizing concepts of citizenship.

Citizenship studies concerning people with dementia have also focused on the institutional contexts in which the provision of social care is organised. 
Österholm \& Hydén (2014) have studied the participation of people living with dementia in assessment meetings and the study show that people with dementia are at times overlooked by care managers due to communication problems and thus, in assessment meetings, represented by relatives for example Österholm \& Samuelsson (2015) and Nedlund \& Taghizadeh Larsson (2016) have problematized people living with dementia as decision-makers in regard to their own situation, the legislation and the provision of social services. Care managers are public officials who assess the need for social services thus both gatekeeping and ensuring social rights for citizens. It is therefore important to study how care managers experience and handle both the group of people living with dementia as well as policies concerning this group. Studies have shown that care managers and other personnel need to develop specific strategies concerning people with dementia in order to handle dilemmas that arise when meeting them (Heinrich et al, 2016; Laybourne, 2016; Österholm et al, 2015).

In the area of social policy other groups have previously been studied. People with disabilities (Dunér \& Wolmesjö, 2015) have previously been addressed. Older people in general have also been studied concerning the provision of social care (c.f Janlöv et al, 2011; Cedersund \& Olaisson, 2010; Olaison \& Cedersund, 2008). However, people living with dementia in the context of social policy and social services have not been the object of many studies. Although social policies and social work have been studied, the experience of street-level bureaucrats, in this case care managers, has been studied to a lesser extent (Forsell et al., 2013; Forsell \& Torres, 2012; Postle, 2002).

To sum up: Social citizenship is aimed at specific target groups, social citizenship is influenced by the actors involved, social citizenship is influenced by the construction of problems as well as the construction of policy targets, The construction of target groups affects their possibility to influence social citizenship and social citizenship is not only formed in policy documents but in policy practices, by citizens with dementia and care manager in their meetings.

Accordingly, it is important to study the processes in which social services are shaped and enacted and it is interesting to do so with the focus on people with dementia. Since, as argued above, social rights are regarded as tied to specific target groups rather than individual citizens (Schneider \& Ingram, 2005; 1997; Stone, 1984) it is central to gain insight in how these target groups are socially constructed. This encompasses how citizens, in this dissertation people living with dementia, have been defined as a target group but also by whom. Furthermore, this entails how they relate to other target groups and if and why they are a target group in their own right or if they are included or excluded to or from other target groups. The social construction of target groups also involves the attributes (Isin \& Wood, 1999; Schneider \& Ingram, 1997; Stone, 1989), e.g. cognitive or communicative functions, which are associated with specific target groups and why they are separated from, or included in other groups. However, whether target groups are considered deserving of specific incentives when allocating public 
resources, depends on whether the ascribed characteristics of this target group, or specific issues connected to this group, can be considered a social problem within the society (Anderson, 2013; Schneider \& Ingram, 2005; 1997). It is thus important to study how policy target groups are constructed and the reasoning behind the construction of specific target groups as well as the ascribed characteristics of individuals connected to these target groups. It is also important to study the solution to specific problems, e.g. which incentives can be tied to specific problems and specific target groups. Social policy, and further social citizenship, is interesting since by studying how incentives, such as social services, are organised and provided it allows us to explore the interaction between citizens, i.e. target groups, and government and also how governments respond to specific circumstances in the "real world", i.e. policies targeted at social problems (Levin, 1997) thus shaping social citizenship. This brings me to my next area of interest which is how policies tied to specific groups are formed and enacted, or formed through enactment, within the Swedish welfare system. In other words, the policy practice which means the situations that public officials, e.g. street-level bureaucrats, encounter in their work and how they interpret, negotiate and create meaning of these situations. Using a citizenship perspective in studying people with dementia will help to assert them as actors within society. Using a citizenship perspective will further shed light on how they are able to form their everyday life, are able to influence social care policies and ultimately social citizenship.

Accordingly, this thesis focuses on the social care policies in Sweden concerning the target group of people living with dementia and is disentangled in the following aim and research questions.

\section{Aim and research questions}

The aim of this dissertation is to explore the social citizenship for people with dementia. Social citizenship for people with dementia is explored by studying how people with dementia, in policy documents, have been constructed as a target group and also by studying how policies are enacted in practice by care managers, in their work and in their meetings with people with dementia.

Social citizenship is displayed by the allocation of public resources to citizens. The allocation of public resources is often directed at target groups in need of specific incentives. In order to understand why and how incentives are targeted to certain groups the policy processes in which social citizenship is constructed needs to be analysed. The presentation of specific target groups as well as the presentation of them as a social problem, will inform policies targeted at them. This entails the construction of the group of people living with dementia, i.e. the images, definitions and attributes that are ascribed to people living with dementia. This also entails how they are constructed as a social problem in regard to the 
Swedish welfare system, and also the underlying knowledge base and rationales upon which these constructions are built. This is disentangled using the following research questions:

-How is the policy target group of people living with dementia constructed in national policy documents in Sweden and has this changed over time?

-Which categorisation, definition, images and attributes have been ascribed to people living with dementia in national policy documents in Sweden and upon what knowledge and rationales are these ascriptions motivated?

Street-level bureaucrats are the officials that citizens encounter in their meeting with the welfare system, and the practices of street-level bureaucrats, in this case care managers, influence public policies. Thus it is also important to gain understanding of the situations which care managers experience when the welfare system encounters the group of people living with dementia. Focus is on how streetlevel bureaucrats, in this case care managers, handle policies concerning the provision of social services for people living with dementia, as well as how they handle implications that arise when they in their work meet people living with dementia.

-How do care managers handle people living with dementia when they encounter the public welfare system?

-How do care managers understand and use legislation and national and local policies they encounter within their work?

\section{The structure of the dissertation}

This thesis is comprised of 6 chapters. Chapter one has given you an introduction which consists of the formulation of a problem, previous research as well as aim and research question. Chapter two (The setting) provides you brief information on the Swedish welfare system. In the third chapter (Theoretical framework) the theoretical framework will be presented which consists of the concepts of social citizenship and policy analysis. Chapter four (Method) gives you a presentation on the methods used in this dissertation with focus on analysis of text and interviews. The methods used will, in this chapter, also be discussed. The four articles will briefly be presented Chapter six. In chapter five (Discussion) findings and future research will be reflected upon. 


\section{CHAPTER 2: THE SWEDISH SOCIAL POLICY SETTING}

In order to get a picture of the context in which this dissertation is placed, its organisation and organisations, a short presentation on the Swedish welfare system is now provided. The focus will be on social services as they are the contextual focus of the dissertation.

\section{The organisation of social services in Sweden}

A rough outline is that the Swedish welfare system comprises three levels. The National level, the regions (previously county councils) and the local level (municipalities). The responsibilities for social welfare are divided amongst these three levels and citizens also have the possibility to vote in these three levels in general elections (Bengtsson, 2012). The organisation of the three levels rests on the notion that decisions on specific issues should lie closest to the affected citizens (Erlingson \& Wänström, 2015; Bengtsson, 2012).

The national level has the formal responsibility for social welfare. In their own regime the national level is responsible for e.g. the pension system and child support (Rothstein, 2010a). However, social welfare is to a large extent managed at sub-levels in the regions and municipalities (Erlingsson \& Wänström, 2015; Montin \& Granberg, 2013). Although the administration of social welfare is managed at sub-levels it is the national level that informs and governs the regions and the municipalities regarding their responsibilities. The sub-levels are thus governed by legislations for example The Local Government Act (SFS 1991:900) and Instrument of Government (SFS 1974:109) and decrees from the state. Specific areas for which sub-levels are responsible are also governed through legislation, for example social services (SFS 2001:453) and health care (SFS 1982:763). The government also create guidelines with which the sublevels have to comply, and judgements through the Courts of Sweden prominently the Administrative Court (Förvaltningsdomstolen). Other ways that government governs sub-levels is through certain incentives aimed at specific policy areas, by for example allocating specific resources to specific policy areas with intended designations (Bengtsson, 2012; Elmér et al., 2000).

The regions have the ultimate responsibility for health care. Health care in Sweden are governed through legislation such as the Health and Medical Services Act (SFS 1982:763). This legislation is a framework legislation which allows that the regions have the possibility to manage their own organisation (Elmér et al., 2000). However, this level and its respective responsibilities are not in focus in this thesis even though there is some cooperation between the munici- 
palities and the regions concerning health and social care for example referring patients to the social services as well as attending care plan meetings.

Important to note is that Sweden is a unitary state. This requires that the municipalities serve as an extension of the state even though they are quite autonomous (Erlingsson \& Wänström, 2015, Bengtsson, 2012; Elmér et al., 2000). Accordingly, municipalities have the responsibility of fulfilling certain obligations aloocated to them by the state. This includes for example to providing schooling, but more importantly for this dissertation managing the social services in Sweden. This includes the social services for people with disabilities and older persons which also is the largest expenditures that the municipalities have even though the budget for taking care of older persons have decreased since the 1990s (Erlingson \& Wänström, 2015; Montin \& Granberg, 2013; Trydegårdh, 2013; Bengtsson, 2012). The municipalities are highly autonomous managing their community. The municipalities have the right to collect taxes and also managing the administration of these taxes by allocating them to different policy areas. The autonomy of the municipalities is based on the foundation that the democracy and the decisions concerning citizens should lie closest to them (Swärd, 2013; Trydegårdh, 2013; Bengtsson, 2012). The municipalities are prominently governed by the state through legislation. However, the legislation concerning the responsibilities of the municipalities is commonly formulated as framework legislation meaning that they only inform the municipalities on their overarching responsibilities but not how to manage them. The legislation that guides the social services is prominently the SSA (SFS 2001:453), the ASS (SFS 1993:387) and also the Administrative Procedure Act (SFS 1986:223). The municipalities are highly autonomous in how to manage their social services in regard to for example older person and people with disabilities as long as they do not stray to far from the legislation. This includes for example which services they provide and the amount of services. It also includes how to manage the delivery of social services for example in its own regime or through private contractors (Trydegårdh, 2013; Bengtsson, 2012). Citizens in each municipality are also free to choose which contractor delivers their services (Trydegårdh, 2013; Szebehely, 2011). Municipalities are also autonomous in other types of organisational management for example on how to organise their political and administrative organisation concerning social services, and how to delegate authority to, for example, care managers. Accordingly, the provision of social services can be organised differently in different municipalities which means that Swedish citizens may be entitled to different services depending on the municipality to which they belong (Swärd, 2013; Rothstein, 2010a; Rauch, 2008), but it is important to note that citizens in each municipality should be treated equally.

To sum up, municipalities are highly autonomous in managing their social services under national level governance. They are highly autonomous in how they manage their political and organisational structure as well as their social services. Although the municipalities commonly have public officials at several 
managerial levels it is the street-level bureaucrats i.e. care managers that encounter the citizens (more on street-level bureaucrats in chapter three), who implement policies and also functions as a gatekeeper for social services (Ellis, 2007; Lipsky, 1980).

\section{The role of care managers in the provision of social care in Sweden}

Care managers are, in Sweden, the public officials who assess and decide on support for citizens who are in need of social care. Other actors deliver the care that the care managers grant the citizens. The provision of social care should be granted according to the legislation and the care managers should make sure that this applies. The care managers should thus make sure that the citizens who encounter the welfare system, when applying for social services, are assessed according to their needs (Dunér \& Nordström, 2005). Care managers thus have delegated responsibility to make decisions on social services for the citizens (Lindelöf \& Rönnbäck, 2007; Dunér \& Nordström, 2005)

However, the role of care managers not only extends to deciding on social services but care managers also have other important functions. According to Lindelöf \& Rönnbäck (2007) and Dunér \& Nordström (2005) care managers have the responsibility of ensuring that decisions made on social services are in accordance with legislation, they have to be loyal to their own organisation whilst also ensuring the interests of the citizens for example making sure that issues concerning social care are raised and also that all citizens are treated equally within their municipality (c.f. Lundquist, 1998). The relationship between the client and the care managers is asymmetric and it is the care manager's function to ensure that all citizens within their municipality applying for social services are treated the same (Dunér \& Nordström, 2005). In order to ensure this care managers create and uphold coherence in their procedures and routines and they follow legislation and policies in a coherent manner (c.f. Elllis, 2014; Dunér \& Nordström, 2005; Lipsky, 1980). However, this implies that they need some form of discretion (see more under the section on street-level bureaucrats in chapter 3), in order to create and maintain their own routines and procedures.

\section{Assessment procedure of social services in Sweden}

The procedure for applying for, assessing and the decisions on social care are regulated in three different legislations, the Administrative Procedure Act (SFS 1986:223), Social Services Act (SFS 2001:453), Act concerning Support and Service for Persons with Certain Functional Impairments (ASS) (SFS 1993:387) and the Local Government Act (SFS 1991:900) (Dunér \& Nordstöm, 2005). Decision by public authorities must be in accordance with legislation. The decisions made by care managers, i.e. the assessment and the decisions on social care must be based in legislation since it is an exercise of public authority. However, the actual provision of social care, i.e. the services that are being performed does not 
have to be in accordance with legislation since this is not regarded as an exercise of public authority (Lindelöf \& Rönnbäck, 2007). Although the services have to be performed in regard to the agreements between the provider and the municipalities.

The assessment procedure can begin in three ways. First and foremost, it usually begins with an application from the citizen in need of social support themselves or from their legal representative/guardian. In those cases, the care managers are obligated to start an assessment concerning that person. Another way that an assessment is initiated is through a request which means that, for example, a relative or a neighbour call attention to a person's need of social services. In these cases, the care managers must ask the person in question if they should start an assessment but the care managers can only do so if the person gives permission. The third way that an assessment can begin is when citizens ask general questions about social services. If the care managers interpret the question as a general question they should answer that question but if they interpret that question as something more they should treat that question in the same manner as they would do with a request (Lindelöf \& Rönnbäck, 2007; Dunér \& Nordström, 2005).

When a care-manager receives an application, either through a direct application or through a request, the care manager is obligated by law to initiate an investigation. The investigation consists of collecting information about the applicant's situation and thus mapping the persons need of social services. It is important to note that the care managers should not take relatives into consideration while assessing the need for support and should decide on provision of social care in accordance with each individuals need and not assume that relatives should take care of some of the services. Exceptions can be made when there is a spouse involved since legislation in Sweden assumes that married partners should take some responsibility for the wellbeing of their spouse (Lindelöf \& Rönnbäck, 2007; Dunér \& Nordström, 2005). During the assessment phase the care-manager should try to find out as much about the person's situation as possible (Lindelöf \& Rönnbäck, 2007) and this is usually done by having conversations with the applicant, and often in their own home in order for the care manager to better understand the everyday life of the person. It is important to document the whole assessment phase as the care managers are obliged by law to do, but also in order for the possibility for the applicant to follow the assessment procedure. Objections and additions from the applicant should also be documented (Lindelöf \& Rönnbäck, 2007).

After the assessment the care managers should approve or deny the application. The care managers should, when deciding on social services, also initiate social care that grants the person a "reasonable standard of living" as stated in the Social Services Act (Lindelöf \& Rönnbäck, 2007). However, exactly what this entails, is not clearly stipulated and a "reasonable standard of living" can thus vary for example between municipalities. The organisation responsible for the provision of social services should provide social care in accordance with the applicant's need (Lindelöf \& Rönnbäck, 2007). Formally, the care managers should not decide on social services in regard to e.g. what is currently accessible 
in the municipality in the form of existing and available forms of services but should always decide on services that fulfil the individual's needs.

If the person is denied, or partially denied, social services they can always appeal the decision. The appeal must be made within three weeks of them getting the notice. It is then decided if there has been an apparent inaccuracy with the decision or if other circumstances have arisen that may change the decision. If there are changes to the decision in accordance with the persons wishes the decision can be implemented directly. If the appeal is denied or if only some of the person's wishes are met the appeal should be sent to the County Administrative Court (länsrätten) for a conclusion (Lindelöf \& Rönnbäck, 2007).

When the applicant receives social care it is the individual that decide on which provider of social care they would like. Earlier the delivery of social services was to a large extent handled by the municipalities in their own regime. However, in recent years more and more municipalities, although not all, have opened up the market of social services delivered by private providers, however this is different in different municipalities. Thus there is a competitive market of social services within some municipalities and the individual who has been granted the social services has to decide which contractors they want to carry out the services they have been granted. This implies that there is more responsibility on the individual to understand the market in which providers of social care operate (Trydegårdh, 2013; Trydegård \& Thorslund, 2010). The provision of social care is thus, to an extent, dependent on the citizen that applies for social care. Citizens must first, of their own accord, apply for services as well as being able to properly formulate their needs and further decide on the providers for specific services. This implies that the provision of social services to a large extent relies on the capacities of the individual citizen.

In this section I have explained the context on which social care are decided upon and provided. In this welfare system there are a lot of processes at different levels and with many different actors e.g. politicians, public officials and care managers who will influence social citizenship. The next section presents the theoretical framework which is used to explain the processes that influence social citizenship. 


\section{CHAPTER 3: THEORETICAL FRAMEWORK}

\section{Introduction to theoretical framework}

It is within public administration that policy decisions become reality and are enacted, as argued by Erlingson \& Wänström (2015) and Kjaer (2004). The enactment of policies will influence social citizenship, and vice versa the enactment of social citizenship will influence policies. However, in order to capture the processes in which social citizenship is constructed, there is need of a model for explaining policy processes. As policies affect social citizenship it is necessary to start by conceptualising social citizenship and social rights. In the next step a theoretical framework for analysing policies and the policy processes will be presented, drawing on the model offered by Schneider \& Ingram (1997).

\section{Social citizenship and social rights}

Citizenship is commonly discussed in the context of rights (Bellamy, 2008; 2001). Rights in the positive, giving the citizens protection and entitlements, range from voting to welfare (Bellamy, 2008; 2001). However, citizenship rights also come with duties such as work, paying taxes and parenthood (Isin \& Turner, 2007). Citizenship and citizenship rights are often divided into political (right to civic and political participation, voting, right to assemble etc.), civil (right to ownership, right to be free of discrimination, right to one's integrity etc.) and social rights (Marshall, 1950). In this thesis the focus will be on social rights and further social citizenship, although these different rights are inter-related (Bellamy, 2001). Social citizenship is closely related to the welfare state and is concerned with the allocation of public goods. Taylor-Gooby (2008, 3) states that social citizenship is "...the rights and duties associated with the provision of benefits and services designed to meet social needs and enhance capabilities...” and thus it makes social citizenship the dominant enterprise of the welfare system. What social citizenship entails is not constant but rather it is fluid and changes depending on for example socio-economic changes, norms, values and migration (Yuval-Davies, 2011; Taylor-Gooby, 2008; Schierup et al., 2006). According to Turner (2001) citizenship is a process and is thus subject to change. Accordingly, social citizenship is a constant formulation of problems connected to the wellbeing and equality of citizens as well as a constant discerning of entitled citizen groups. However, which citizen groups are entitled to specific incentives and thus entitled to specific social rights is something that is constructed and individuals are not merely born as citizens but are constructed as such (Cruikshank, 1999). This implies that all citizens are not equal according to the state but rather the target for incentives in order to make them more equal. By 
that, social citizenship is about inclusion and exclusion, both of the social rights as well as the processes that influence these rights. This entails the discerning of who is entitled to social rights. Constructions of citizens are based on who is the ideal citizen and who is a problematic citizen which is decided by shared values (Anderson 2013; Jordan, 2003; Schneider \& Ingram, 1997; Dahl 1989) and citizens enjoying social rights must thus display a genuine incapacity in order not to unnecessarily burden society (Jordan, 2003). However, who is an ideal citizen or a problematic one is a constantly ongoing discussion within the welfare system.

Depending on the welfare system and its formulation of social problems categories of citizens will be marginalised, de-marginalised and constructed and also presented in form of problems (Daly, 2011; Rodger, 2000), e.g. women (c.f Lister, 2003), people with disabilities (c.f. Oliver, 2009; Priestly, 2003) and older people (Jönson, 2002, Nelson, 2002; Bytheway, 1995). Social citizenship and social rights is thus a constantly ongoing formulation of problems and a discerning of specific target groups to include and exclude from the welfare system (Isin \& Turner, 2007). However, social rights are not often bestowed upon specific target groups. Rather it is a claims-making or campaigning for rights of specific target groups either by themselves or by advocates that causes awareness of specific problems (Johansson \& Hvinden, 2007a; 2007b). Bellamy (2001) argues that citizenship is not the passive acceptance of rights. He argues that social citizenship and social rights are not only about accepting or claiming rights but also about citizens having the possibility to influence and to form these rights. To influence social rights can be done in different ways, by being able to vote, by being able to demonstrate but also by bringing new cases to the institutions of government, e.g. courts and public administration (Bellamy, 2008; 2001). By doing so citizens bring new situations to policy areas which have to be considered in the formation of social rights and further social citizenship (Bellamy, 2008; 2001; Wagenaar \& Cook, 2003). Accordingly, the discerning of problems and of target groups as well as the formulation of policies are not only the enterprise of government but also of the citizens.

Welfare is something that has been present in all societies throughout history and is considered a way to prevent and reduce human hardship. Welfare and welfare policies is considered as "social, economic and ethical systems which indicate how specific social problems should be handled” (Qvarsell, 2013, 64) or as a way of "enhancing the welfare of vulnerable groups of people in society and offering or facilitating social protection for all” (Van Kersbergen \& Vis, 2014, 2) and to provide conditions in order for citizens to live their life on their own conditions (Kvist et al., 2012). In all communities there has always been a relationship between the healthy and the sick, the fortunate and the unfortunate and even though it affects individuals differently welfare has always been a question for the community to which individuals belong, but how welfare should be organised and who is included has changed. In different communities, welfare has been the object for different organisations, e.g. the church or the civil society but today 
welfare is closely related to the national state and its responsibility for the wellbeing of its citizens (Qvarsell, 2013; Daly, 2011). Even though welfare is different in different communities it encompasses how we collectively solve social problems for example income inequality or health issues (Van Kersbergen \& Vis, 2014). The welfare state is constantly mapping out social citizenship by defining the responsibilities of its citizens as well as the eligibility requirements for social services (Dominelli \& Moosa-Mitha, 2014). In this thesis I will refer to Swedish welfare as a welfare system since it entails different organisations, both governmental and civil organisations as well as relatives. However, the focus in this thesis is on the relationship between the citizens and public administration.

Who becomes a citizen and what becomes social citizenship and further the social rights of citizens, is based on rationales and logics (Stone, 2012). Even if these rationales are not motivated by being scientifically viable they rest on values that each society promotes, e.g. equality, freedom, on driving forces such as demographic changes, migration, economic crisis as well as actors with different interests and ideas (Van Kersbergen \& Vis, 2014; Daly 2011).

In order for social rights to become legitimate there has to be some sort of reciprocity (Taylor-Gooby, 2008). Reciprocity here lies in that the rights, for example social services, are equal for citizens in an equal situation. Since social services are funded by taxes, and therefore partially funded by the citizens, the providers of social rights must live up to a certain standard and also maintain legal security, as well as ensuring that services do not become arbitrary. In the welfare system where social services are provided by the municipalities and further delivered by, to an extent, private companies, the reciprocity lies within a decent provision of social services in order to maintain legitimacy, otherwise running the risk of protest or the risk of citizens leaving the municipality for another one (Jordan, 2003). However, in order to receive social rights reciprocity is also required from the citizens in order to be able to enjoy those rights (Jordan, 2003) such as, mentioned earlier, work, paying taxes, parenthood etc. (Isin \& Turner, 2007).

People within communities have always been exposed to hardship such as difficulties in providing for themselves and their families, sickness and injuries which have to be dealt with (Qvarsell, 2013). All societies have some kind of welfare in place to handle these sort of problems but how that welfare has emerged and become organised differs between societies (Daly, 2011). Accordingly, social citizenship and social rights can be organised differently in different communities.

Sweden is a state governed by law, which means that the citizens should be able to predict their social rights, and decisions on social services for example are based in regard to legislation (Rothstein, 2010b). This means that the individual citizen should be able to predict the events and actions when they encounter the welfare system. The rule of law has thus a two-way function, on one hand it functions as a way to make citizens comply with the intentions of the state, e.g. not commit crime or be punished for doing so. On the other hand, and perhaps more importantly concerning the focus of this thesis, it functions to ensure that governments, its institutions and the officials of governmental institutions fulfil 
their responsibilities in a just and non-arbitrary manner (Bellamy, 2003;2001). It also requires that social services for e.g. education, health care, social care are efficient and effective for individual citizens when they need such services (Taylor- Gooby, 2008). Accordingly, social citizenship is dependent on how we organise welfare and the distribution of social services. Social citizenship is mainly comprised of the rights that citizens enjoy when they are in need, and also encompasses the possibility for specific groups of citizens to have access to these rights. However, there are differences in formal and substantial rights. Formal and substantial rights entail two aspects. The first is that all citizens do not have the same opportunity to receive specific incentives, e.g. social service, even though they are formally entitled to them. This is a question of inclusion and exclusion and is based on notions of which citizens count as members but also how these members should be constituted (Isin \& Wood, 1999). Another aspect of formal and substantial rights is how these rights are implemented. Even though certain rights are specified in legislation and other policy documents, it is not certain that these rights are the same in practice, it is therefore what citizens actually receive that constitute the substantial rights (Rothstein, 2010a). Concepts of citizenship, especially social citizenship, is of importance for social work, and social workers, since their work is influenced by the values, such as equality and democracy, that we ascribe to citizenship and also how we form the problem formulation of who is entitled and what the requirement for entitlement is. Social workers must respond to the changes of citizenship regimes in their work as an extended arm of the welfare system. Accordingly, they are influenced by their concepts on citizenship, as well as influencing social citizenship and social rights (Dominelli \& Moosa-Mitha, 2014).

Social citizenship is influenced by the policy processes and what these processes entail, and the norms and values upon which they are based, which actors are present and what knowledge that helps shape specific policy areas. A way that governments govern is through policies such as legislation and guidelines. In order to understand how social citizenship is formed and why it is formed in a specific manner we need to gain understanding about the processes which help to shape social citizenship. Policy analysis is a theory and a method for discerning political processes (Rein \& Schön, 1996) and in this dissertation policy analysis will be used as a way to understand how social citizenship and social rights concerning people living with dementia have been formulated and also enacted by street-level bureaucrats.

\section{Policy analysis}

Accordingly, in order to solve problems, governments use policies. However, policies must not only be formed and implemented but have to be designed and policy design involves specific elements which influences how policies can be formed (Schneider \& Sidney, 2009; Schneider \& Ingram 1997). Before I explain Schneider \& Ingram's (1997) model of policy design I will present an explanation of how to understand what policy is. 


\section{Understanding policy?}

Policy in this dissertation will be divided into two parts, policy and policy practice. In this research both of these parts concerning policies are at play and will be investigated through different articles. However, these concepts do not stand alone each on their own but can rather be seen as part of a dynamic process and are therefore inter-related to each other. It is thus difficult to create a division between these two.

Policy is, in this dissertation, considered as an intentional solution to a social problem, i.e. a specific policy document or as a way of handling a specific problem. However, it does not have to be written explicitly as a policy document, in specific texts, e.g. legislation, but could also be in practice i.e. homework policy in schools or as routines created by actors involved in the policy-making process (Nedlund, 2012; Colebatch, 2002, Levin, 1997; Schneider \& Ingram 1993).

Policy practice is a way of handling issues. Yanow (2015) states that policy practice is a form of policy enactment and its related practices. Beginning with Lipsky's (1980) critique that public officials, working as street-level bureaucrats, not only implement public policies but these policies are subject to local interpretation by street-level bureaucrats. This ends up in what the clients, e.g applicants for social services, perceive as governmental public policy (Yanow, 2015). In this sense public officials do not uncritically implement policies but also enact policies. Accordingly, policy practice is affected by social, professional, organisational, institutional and political experience of a policy worker situated in a specific context (Turnbull, 2013) and an example of policy practice is how streetlevel bureaucrats, e.g. care managers, interpret, make sense and meaning of policies and how they manage practical issues in their everyday work situation (Brodkin, 2011; Wagenaar \& Cook, 2003). Policy practice that becomes a routine for example, can thus be considered a policy.

The policies that are studied in this dissertation are related to public administration. Public policies are means by which governments can create solutions to problems (Hajer, 1993; Schneider \& Ingram, 1993). Further the policy that is studied in this thesis is social policy. Social policy comprises policies concerning the area of social welfare and is the practice that aims at securing the well-being of citizens. Social policy encompasses several policy areas, such as education and social security benefits (Alcock \& Fergusson, 2012) but in this dissertation social policy is within the area of social care and social services.

\section{Analysing policies}

Policy analysis seeks to "identify and analyse the political game of interests and powers that is at stake in any given policy issue" (Rein \& Schön, 1996, 93). Policy analysis can be seen both as a theoretical framework as well as a practice. By gathering data, the researchers seek to, with a distance approach, analyse policies, e.g. possible goals, problems and solutions and the choice of appropriate policies (Rein \& Schön, 1996). According to Craft (2015) theories about the policy process is not a uniform whole but rather a collection of streams that study the events practices, actors and contexts upon which policies are formed. In the 
studying of policies scholars often rely on various theories which include different frameworks and models for analysing the policy process (Schlager \& Weible, 2013). In this thesis the theoretical framework of policy analysis is policy design theory. Schneider \& Sidney (2009) and Schneider \& Ingram (1997) argue that policy is always designed. This means that all policies have a specific architecture and the enterprise of policy analysis is to, in any given policy area, discern the elements that together make a design. Policy theorists should further investigate the social construction of knowledge which influence policy design, investigate the relationship between policy elements as well as empirically analyse the impact that policy design has on the assertion of voice and social movements. In order to do so the theoretical framework for this thesis is built upon Schneider \& Ingram’s (1997) model of policy design.

\section{Policy design}

Schneider \& Ingram (1997) argue that policies are always designed. They have discerned several elements that are in play in the policy design process. This model includes the elements of goals, problems, rules, agents, targets, solutions, rationales and implementation structures (see Table 1.) and in the following section I will explain these elements. The element of agents has been expanded to include street-level bureaucrats, since a focus in this dissertation is on care managers as important policy actors working as street-level bureaucrats.

\section{Goals}

Schneider \& Ingram (1997) refer to the element of goals as what to be achieved through policies. Goals are thus an indication of the conceptions of the state and its intentions, for example to provide social security for its citizens. Goals can be explicit or implicit; they can be realistic or unrealistic, conflicting or consistent. Goals are, even though described in technical terms, constructed as problems (Stone 2012; Schneider \& Ingram, 1997).

Often there are essential goals that governments commonly try to attain such as equality, liberty, prosperity, efficiency and security which are embedded in cultural norms and values (Stone 2012; Schneider \& Ingram, 1997). Welfare and equity are common goals that are usually endorsed by the public and that government should provide at least some kind of basic welfare for its citizens (Stone, 2012). Even though these goals are essential to society there are several ways to define them as well as to attain them. This means that there are no fixed goals, and even if there were there is not a single way to define them which results in a struggle over which definition and meaning to ascribe to specific goals (Stone, 2012; Colebatch, 2002; Schneider \& Ingram 1997). 
Table 1.

\section{Elements in Schneider \& Ingram's (1997) policy design model}

Goals Considered as what to be achieved by society. They give indica-
tions of conceptions of the state and often entail overarching in-
dications on what to strive for, e.g. equality, liberty, security.

Problems Problems are not objectively "out there" for us to find. Rather problems are constructed in relation to society. Accordingly, problem formulation can change over time and is formulated by the actors involved.

\begin{tabular}{ll}
\hline Rules & $\begin{array}{l}\text { The rules tied to a specific policy. The rules are set by, the for } \\
\text { example, the policy area. }\end{array}$ \\
\hline Agents & $\begin{array}{l}\text { The actors involved in the policy process who also aim to influ- } \\
\text { ence this process. Agents can be politicians, public officials, tar- } \\
\text { gets, advocates etc. A specific focus in this dissertation will be } \\
\text { on street-level bureaucrats as agents. The public officials who } \\
\text { encounter the citizens and are considered as implementing poli- } \\
\text { cies. By exercising discretion, they add values to policies when } \\
\text { handling issues they encounter in their everyday work. }\end{array}$ \\
\hline Targets & $\begin{array}{l}\text { The group towards which policies are directed. Target groups are } \\
\text { constructed and are given definitions and specific attributes that } \\
\text { need to be solved. }\end{array}$ \\
\hline Solutions & $\begin{array}{l}\text { Often described as the end-game of policies, as the solution to a } \\
\text { discerned problem. However, the solutions are commonly pre- } \\
\text { sent during the whole policy process and influence other ele- } \\
\text { ments. }\end{array}$ \\
\hline Rationales & $\begin{array}{l}\text { Rationales are the overarching justification for problems and so- } \\
\text { lutions. Rationales consist of norms and values and are often sci- } \\
\text { entifically substantiated. Rationales do not have to correspond to } \\
\text { reality. }\end{array}$ \\
\hline Implementation & $\begin{array}{l}\text { Implementation is the part of the policy process where policies } \\
\text { are explained as put into practice, or enacted. However, imple- } \\
\text { mentation should not be considered as the last stage of the policy } \\
\text { process since this element may affect the policy and also influ- } \\
\text { ence policy design. }\end{array}$ \\
\hline
\end{tabular}


Even though politicians do not intend to solve problems linked to goals they may use goals as a way to legitimise certain policy design and as a way to respond to public interest. Accordingly, goals can be defined as a way to respond to public interests, but in "reality" they respond to narrower issues with selected target groups. Goals are thus a basis on which to design policies and further to construct policy target groups (Schneider \& Ingram 1997).

\section{Problems}

Problems are closely related to goals since goals are used to discern specific problems and also specify what is to be achieved by policies and further specify the intentions of the state (Schneider \& Ingram, 1997). Even though problems are presented as objective, they are socially constructed and attention is given to the problem as well as the desired ends. This means that there are no readily identifiable problems but they only become such after being defined as a problem, and policies are thus embedded in the representation of a problem (Bacchi, 2009; Schneider \& Ingram, 1997; Blumer, 1971). However, a problem does not become a social problem due only to it being presented as such, but it has to be legitimised as a social problem by being socially endorsed and acquire recognition and respectability, which entitles it to become a part of the public debate (Stone, 1984; Blumer, 1971). How we define and categorise certain phenomenon is the starting point for when a social problem is born. Deviance and dysfunction, for example dementia, is not a problem in itself and can only become one after the societal definition gives it the construct of being a problem (Blumer, 1971). As problems are constructed there are no readily identifiable problems but rather a claims-making to social problems, someone need to claim the right to certain incentives as they are a target group or advocates for specific issues. Social problems become such after interpretation, they can be seen as oppressive, intolerable or unjust, as such different target groups will receive burdens or benefits in accordance of the problem formulation (Schneider \& Ingram 1997), and accordingly the description of problems also comes with a recommendation on how to address the specific problem (Stone, 2012; Schneider \& Ingram, 1997). As such problems are never value-neutral, nor are they rational in a way that results can be measured and judged (Stone, 2012; Schneider \& Ingram, 1997).

However, there is no single construction of a problem, actors involved in the social construction of a problem may have different views, and actors portray problems in a strategic manner in order to gain leverage on other actors (Stone, 2012). Problems can originate from claims-making from oppressed groups (Spector \& Kitsuse, 1973; Blumer, 1971), or as discerning from other actors (Stone, 2012; Schneider \& Ingram, 1997). Hajer (1993) argues that actors involved in creating a problem do not necessarily share knowledge, beliefs or values although they do agree upon a shared construction of a problem and thus create a storyline about specific policy problems (Hajer, 1993).

Important to note is that there is a never ending formulation of problems. This is what Stone (2012) refers to as a policy paradox. The handling of one problem leads to another problem. 


\section{Rules}

Which design a policy has, depends on which target group the policy is targeted at (Schneider \& Ingram 1997). The design indicates the rules tied to a specific policy and the rules describe which actor is to do what. Rules define who are eligible for the policy and these can be universalistic, which aims at covering nearly all the population, while particularistic rules aim at targets which meet certain criteria. How clear these rules are, varies a lot as they can be vague or clear. Discretion is also different between different policy areas and can either be strict or open for local interpretations.

Rules also function as a re-enforcement of previous distribution of power, since the eligibility for specific policies may reproduce conceptions of specific target groups. Rules of eligibility also function as an indication of the level of policy. Some eligibility has legal connotation which also imply an aspect of rights. Some policy is designed to produce actions whatever the costs, where some are weighing costs against benefits (Schneider \& Ingram, 1997).

Different policy areas and different target groups tend to have different rules on how they ought to be designed. Policies aimed at economic issues tend to be designed differently to those aimed at social issues. Rules are also affected by contextual and historical factors within a specific policy area but different policy areas also affect others (Howlett, 2015; 2014; Colebatch et al., 2010). One policy area can be influenced by other policy areas since they for example cannot contradict each other without losing credibility, environmental policy loses credibility when it is contradicted by a road policy (Colebatch, 2009).

How rules are being designed has impact on democracy. Flexibility may provide more positive conceptions and are thus considered more democratic while strict rules provide the opposite (Schneider \& Ingram, 1997).

\section{Agents}

Schneider \& Ingram $(1997,89)$ define agents as "means for delivering policy to target population”. Since social problems are socially constructed, the policy process is influenced by actors trying to influence the policy design. Agents are able to influence changes to all elements of the design, for example goals, problem formulation, tools and rules, and the value adding can be conceived as the difference between the received design and the design produced by any actor in the policy process (Schneider \& Ingram, 1997). As such the policy process is always influenced by all the actors involved (Colebatch et al., 2010; Schneider \& Ingram, 1997). Actors involved in the policy process work as agents for specific policy programmes and thus influence the formulation of policies by conforming to them or by re-programming them in order to invoke change. Agents are thus involved in the struggle for continuity or for change (Considine, 2005). However, as policy areas change the possibility for actors to influence the design may change. Actors come from a wide range of areas in which some areas are given more influence. However, this can change over time and actors that are given more influence in one policy area may not have that possibility in others (Weible, 2008). Accordingly, the policy process is not value-neutral and all actors influ- 
ence the design throughout the policy process (Schneider \& Ingram, 1997; Fischer, 1993).

The ability to influence the policy design depends on the discretion given by the policy design. Discretion can be either weak or strong (Schneider \& Ingram, 1997; Dworkin, 1977). For example, “strong statutes” have a built in limitation to discretion which leaves little room for actors to add values to the policy design. This is related to strong authority at the top and is designed to reproduce the policy design faithfully. "Grassroots" on the other hand is designed to give discretion to the agents who enact policies. Goals and problem formulation is left quite open here and it is the objective for "lower-level" actors to find solutions to problems that arise in their work (Schneider \& Ingram, 1997).

\section{Targets}

When designing policy there is always a target for that policy. The construction of targets is essential when allocating resources between different citizen groups (Stone, 2012; Schneider \& Sidney, 2009; Schneider \& Ingram, 1997), and in the arena of social policy, concerning the issue of allocating resources between different citizens, the target is commonly a group of people (Schneider \& Ingram, 1997), such as people living with dementia. Schneider and Ingram (1997, s 75) describe the social construction of target groups as "the images, stereotypes, and beliefs that confer identities on people and connect them with others as a social group who are possible candidates for receiving beneficial or burdensome policy". How they are constructed depends on the strategy which is used by policymakers in order to achieve goals and solve problems but also in the knowledge upon which these constructions are built (Stone, 2012; Schneider \& Sidney, 2009; Schneider \& Ingram, 1997). Policy targets are essential within policy design since they also have to produce, meaning that in order to solve problems or achieve policy goals they have to behave in a certain way and thus targets have an important role in policy design (Schneider \& Ingram, 1997; Stone, 2012; Colebatch, 2002). In order to minimise the extent of enforcement, government often relies on target groups to comply with the policy design (Schneider \& Ingram, 1997).

There are often several policy targets, such as people living with dementia, from which to choose when designing policies and they can be chosen on different bases such as need, merit, fairness, equality, political power or wealth (Schneider \& Ingram, 1997; 2005; Stone, 2012). Which policy design you create depends on which category of group the target is (Schneider \& Sidney, 2014; Schneider \& Ingram, 2005; 1997). Schneider and Ingram (1997) divide target groups into four categories, advantaged, contenders, dependents and deviants. Advantaged are often constructed in a positive manner and have political power (scientists, military, middle class). Contenders also have political power but have a negative construction (rich people, CEOs, companies). Dependents are those who have mainly a positive construction but are politically weak (children, mothers and the poor). Deviants are considered politically weak at the same time as they are negatively constructed (criminals, drug addicts). The category of targets decides how to allocate resources, some categories only receive burdens, 
some only benefits and some categories receive both (Schneider \& Ingram, 1997, 1993).

However, policy design often incorporates several target groups. This can be intentionally or unintentionally. When designing policy there might be a proximate group on which to design the policy but there may also be other target groups that are affected by the structure of the policy design. The incentives received may be different for target groups down the chain than for those that are the primary receptors of the incentive (Schneider \& Ingram, 1997).

How policy target groups experience policies targeted at them, or how other groups experience them, has an impact on how citizens view government, and how certain policy target groups are treated in policies, can either strengthen or weaken the legitimacy of governments (Schneider \& Ingram, 1997).

\section{Solutions}

The solution to social problems is affected by all of the elements in this model. In a rational way of thinking about policies, the solution is the endgame of the policy process, e.g. the part that is supposed to eradicate the problem. However, a solution is not something that is only in effect after the policy problem is discerned, but it also influences the policy choices. Restrictions in for example economical or structural solutions, may affect the formulation of problems e.g. if there are not enough institutions in where to place a specific target group, e.g. people with dementia in residential homes, then the problem formulation and the solution to that problem may be formulated in solutions that promote home-care (Stone, 2012; Schneider \& Ingram, 2005; 1997). Accordingly, solutions are apparent in the whole policy process and affect other elements such as problems as well as rules and tools. Solutions, according to Stone (2012), will also be followed by another problem formulation, which thus presents a paradox.

\section{Rationales}

Rationales help explain and justify, thus also legitimise, the policy design, they justify the agenda, the target groups and the rules and tools to achieve a specific goal (Stone, 2012; Schneider \& Ingram, 1997). Rationales are contextual and help policy makers to argue that the policy design is responsive to the specific issue and rationales is the bases that tie the elements together such as target groups, rules and implementation. Rationales give the society indications on the values of the society and also relate different target groups to those values (Schneider \& Ingram, 1997).

Important to note is that rationales, the same as goals and problems, are socially constructed and thus not value-neutral, and they do not have to conform to "reality” (Fischer et al., 2015; Schneider \& Ingram; 1997). However, they have to be, if not conforming to "reality", at least plausible within the context they are used, and accordingly have to be endorsed by, for example, our conceptions of "reality" and by scientific results. However, rationales are ineffective if the construction of the policy area changes. The rationales can thus be invalid if the constructions of goals and problems change, so there has to be a coherence between 
these different elements in order for rationales to legitimate certain courses of action (Schneider \& Ingram, 1997).

Rationales can be very powerful within the policy process if they are unchallenged. Rationales built on stereotypes often tend to guide the policy design both in the "higher" levels, guiding the policy making, as well as on the "lower" level by guiding the policy practice. However, policies built on stereotypes will not be considered legitimate in many societies but if they go unchallenged they will still influence the policy design (Schneider \& Ingram, 1997).

\section{Implementation}

Schneider \& Ingram $(1997,89)$ refer to implementation as the "value added to design". As policies contain a blueprint the values added are considered as the changes to the blueprint, which include changes to goals, rationales and tools for example, by any actor involved in the policy design.

Implementation is often explained as lower level agents enacting the higher level agents' decisions without adding values to the "actual policy", and deviance from that policy is considered a failure (Pressman \& Wildavsky, 1984; 1973; Sabatier \& Mazmanian 1979; Bardach 1977; Van Meter \& Van horn 1975).

In opposition Schneider \& Ingram (1997) argue that implementation is the changing of, deletion from or adding to the policy design. Values added can be regarding one or several elements, such as target group, rationales, goals, and the implementation of a policy can be conceived as the difference between the "design received and the one produced by a particular actor in the system" (Schneider \& Ingram, 1997, 89). Accordingly, implementation is not the sole enterprise of the actors on the ground floor. Wagenaar and Cook (2003) state that the implementation is not detached from the policies but rather it should be seen as part of the policy process. However, the lower-level actors may be more familiar with the context in which the policy is implemented and thus add their own values (Schneider \& Ingram, 1997).

The implementation of policies should not be seen as following a specific order where subordinates unreflectively incorporate decisions into their practice. For those implementing policy there is an interpretation, a re-formulation in order for the practitioners to solve the everyday issues that they encounter in their work tasks. By interpreting and re-forming the policies they should implement they also make it possible to develop or change them. Wagenaar \& Cook (2003, 165) state that "In the course of designing novel solutions to concrete, practical issues, practitioners, the people on the shop floor, literally bring new realities into being”. The implementation of policies often emanates from the "actual" policy, e.g. legislation and guidelines, but in practice the actors make meaning of them, translating them to fit their situation (Wagenaar \& Cook, 2003). The "same” policies can then differ between organisations or between different members of the staff (Wagenaar \& Cook, 2003), although within the specific framework given by the formulation of the policy design and the policy area. In Sweden implementers of policy, e.g. care managers, have a strong degree of professionalism and are bound by legislation in their work practice (Rothstein, 2010b). Accordingly, they are governed by the policy design, legislation, policies and guidelines, and if they 
stray too far from them the social trust regarding the social rights is at stake. However, the possibility of choice by the actors that implement policies and the possibility for them to interpret and negotiate policies is an undisputed part of the implementation process.

\section{The role of street-level bureaucrats}

Schneider \& Ingram's (1997) model entails the element of agents. In this dissertation one focus is on care managers. Accordingly, street-level bureaucrats as agents are here more thoroughly explained. Bureaucrats in public administration display the most decisive element in the allocation of the welfare systems resources (Keiser, 2001; Heclo, 1994). For example, care managers have the legislative delegation to make decisions on behalf of the state regarding social services (Lindelöf \& Rönnbäck, 2007). Street-level bureaucrats are the public officials that work within the borderland between the state and the citizens, e.g. teachers, police officers and care managers (Brodkin, 2011; Maynard-Moody \& Musheno, 2000; Baldwin, 2000; Lipsky, 1980). Street-level bureaucrats are attaining organisational goals by policy enactment (Yanow, 2015; Lipsky, 1980). Street-level bureaucrats are serving as gatekeepers for the public where they decide on which applicant is eligible for e.g. social services and which are not. As such they are responsible for ensuring that public goods are allocated to citizens in need and where the citizens have to display their need, which care managers, as gatekeepers, assess. As such they have loyalties to their organisation (Arnold, 2014; Tummer \& Bekkers, 2014: Ellis, 2007; Lipsky, 1980). However, streetlevel bureaucrats also tend to the interests of citizens by for example making sure that they are assessed in accordance with legislation, by trying to maintain just decisions, maintaining equality before the law, by reducing arbitrariness in decisions as well as conveying the interests of the citizens to their organisations (Maynard-Moody \& Musheno, 2012; 2000; Gofen, 2013; Durose, 2011; Maynard-Moody \& Musheno, 2000; Lundquist, 1998). In contrast to politicians and senior administrators who tend to see citizens as abstract categories of target groups, street-level bureaucrats work in concrete situations where they encounter citizens. This creates situations for street-level bureaucrats that do not always fit neatly with the intended legislation and policies (Wagenaar \& Cook, 2003; Maynard-Moody \& Musheno, 2000; Lipsky, 1980). Accordingly, the situation for street-level bureaucrats is concrete, action-oriented and urgent and at the same time open-ended which makes their work difficult to predict and routinise (Wagenaar \& Cook, 2003; Maynard-Moody \& Musheno 2000; Lipsky, 1980). Street-level bureaucrats must solve the issues at hand in the situations that arise and sometimes use unsanctioned methods when handling dilemmas as well as working in contradiction to policies (Brodkin, 2011; Wagenaar \& Cook, 2003), but also maintaining their professional role in order to maintain legitimacy (Ellis, 2007).

That street-level bureaucrats have the possibility to interpret policies, create their own routines as well as solve issues at hand implies that they have professional discretion. Discretion is the action or non-action in specific professional situations (Tummers \& Bekkers, 2014; Carrington, 2005), the possibility to in- 
voke one's professional expertise and the possibility to interpret and negotiate situations and policies to fit the situation at hand. Discretion can vary depending on the implementation structure and thus affect the possibility of handling policy design flaws (Schneider \& Ingram, 1997). However, discretion can prove problematic since strong discretion can create flexibility for street-level bureaucrats in solving issues in a, for them, suitable way, but also risks straying to far from intended policies, thus creating unpredictability. Creating ways of handling issues, procedures and routines must therefore be done collectively (Ellis, 2007) in order to maintain coherence over a department for example. Weak discretion on the other hand inhibits self-management and one's own problem-solving, and organisations with weak discretion tend to be controlled from the top down (Drury, 2014; Dworkin, 1977). In order to maintain public trust, social workers must display what Clarke et al. (1994) refer to as "bureau-professionalism”, which entails considering bureaucratic rules at the same time as being able to consider individual circumstances (Ellis, 2014), and this is apparent in Sweden in order to legitimate the state as the allocator of public goods. The decisions on social services rests on the foundation that they are based on professionalism, bureaucratic rules and without arbitrariness, so that each individual can predict the outcomes when they encounter the welfare state. Since social services are carried out to a large extent by administration and its officials, it falls to the street-level bureaucrats to ensure "bureau-professionalism” (Rothstein, 2010b; Clarke et al., 1994). Thus there is a tension between legislation, policies and practice, and also between weak and strong discretion (Schneider \& Ingram, 1997; Dworkin, 1977) in relation to ensuring both professional decision-making at the same time as ensuring the rights of citizens.

\section{Summary of theoretical framework}

Social citizenship encompasses the social rights that citizens enjoy. Social citizenship concerns the wellbeing of the citizens and commonly includes rights such as social care and social services. The formation of social rights, what they contain and to whom they are given, that citizens should enjoy, is an ongoing process and is thus likely to change over time. Social citizenship and social rights are influenced by several actors in the welfare system such as governments, citizens and advocates. Accordingly, social citizenship is the discerning of social problems and the solutions to those problems, but also the discerning of target groups (citizens). Accordingly, there is an inclusionary and exclusionary aspect of social citizenship and of those who are considered a citizen.

The aim of this dissertation is to explore the social citizenship for people with dementia. Social citizenship for people with dementia is explored by studying how people with dementia have been constructed as a target group in policy documents and also by studying how policies are enacted in practice by care managers, in their work and in their meetings with people with dementia.

In order to analyse social citizenship and social rights Schneider \& Ingram's (1997) model of the policy process has been used. The elements in their model capture social citizenship by discerning the processes involved in forming social 
citizenship and help us to understand and analyse how social citizenship is formed. Social citizenship is a constant problem formulation, and elements such as goals, rationales and problems may help to identify specific problems and also how they are constructed, and formulated and on which logics and knowledge this construction is based. Looking at elements such as solutions, rules and tools shows the "playing field" to which policy actors have to comply, e.g. all solutions are not possible in all policy areas. Elements such as targets and agents help to understand the actors involved in the policy processes that shape social citizenship, what the policy target group incentives are aimed at and also how this target group is constructed. Implementation and the section on agents and street-level bureaucrats help to analyse the borderland where citizens meet the welfare system and the practices in which social citizenship is enacted and also to analyse the actors involved. 


\section{CHAPTER 4: METHOD}

\section{Method}

In this section the method for this dissertation will be presented. The material and the different analyses will be presented and also a discussed. The quality of the research will also be addressed.

\section{Qualitative textual analysis}

The method in this dissertation is qualitative textual analysis. However, the qualitative textual analysis has been carried out with different approaches (c.f. Bryman, 2012; Esaiasson 2012). The material consists of policy documents from national level and interviews with care managers from municipalities in Sweden. Even though interviews were conducted the material from the interviews has been treated as texts in the analysis (c.f. Bergström \& Boréus, 2012).

\section{Document study}

Documents commonly exist within a specific context and serve as a base for understanding and studying social phenomena (Lewis, 2012; Feldman \& Singer, 2007). The policy documents have been analysed using two different analyses, a narrative approach and a textual content analysis. In the following section the collecting of material will be presented as well as the two methods for analysis.

\section{Collecting policy documents}

The documents were collected at a national level and include for example policy documents i.e. legislation, guidelines, reports, investigations etc. from the Government Offices (Regeringskansliet) and the National Board of Health and Welfare (Socialstyrelsen). The documents that were selected span over approximately 40 years starting from the end of the 1970's up to 2014. During the searching and selecting of documents the focus was firstly on all policy documents that revolved explicitly around people with dementia. Search words such as "dementia”, “demented”, "people with dementia” and "relatives” were used in order to find related policy documents. The search was also extended to involve other search criteria such as "older people”, "mental illness”, "people with disabilities” and "elderly care”, "social care”, "social support” and "social services”. All search words were used in different combinations. The extended search was intended to cover policies concerning people with dementia even though they were not an explicit policy target group in some policy documents, but associated with other target groups. To clarify, when selecting documents, the criterion was not that people living with dementia had to be an explicit target group but that the documents could cover people with dementia. This was especially the case in the early documents since people with dementia were starting to emerge as a target 
group in policy documents by the end of the 1970's. This was also the reason for starting the search in order to cover the years before people with dementia were becoming visible in policy documents. Therefor there was a wide search of documents. During the search the webpages of the National Board of Health and Welfare and the Government Offices were used. The library was also searched for policy documents concerning people with dementia. A request was made, using the search words, at the National Archives in order to see if we had missed any relevant documents, however that search did not add any new documents. The more recent documents could be downloaded as pdfs and the older ones were borrowed from the library, archives or offices and were then copied and converted to pdfs. Our collection of documents can be understood as static which means that the corpus of data has not evolved over time (Feldman \& Singer, 2007) but a set of data was collected and then analysed. Our corpus of documents comprised 165 documents.

\section{Analysing policy documents through narratives}

The first analysis of policy documents was a narrative analysis (c.f. Phoenix et al., 2010). In this dissertation a narrative is considered as a collection of particular events that give a coherent account (Gubrium \& Holstein, 1998). An important goal of narrative analysis is to understand both what, i.e. substance and the plot of the story, as well as how a story is being told (Gubrium \& Holstein, 1998). Narratives are powerful in the creation of policies and narratives make policies more resilient to change (Shanahan et al., 2013; Stone, 1989), and in this part of the dissertation (article I) the focus has been on policy narratives. Miller (2012) argues that the policy process is built upon several competing narratives that shape that policy process and Shanahan et al. (2013) argue that narratives are a way to understand the social construction of policy realities. The policy process is built upon knowledge and beliefs which do not belong to single actors, but rather forms a narrative combined from several actors and their particular stories. Policy narratives are thus inter-subjective (Shanahan et al., 2013).

The analysis of policy documents started by identifying different stories, also referred to as accounts. The identified stories mirror cultural and social constructions. The accounts were then synthesised into a master narrative. In that sense the master narrative was co-created by the authors. Phoenix et al. (2010) explains narratives as several accounts with specific events and characteristics that together make a broader story. When analysing the documents, the focus was on several things. First of all, the different constructions that people living with dementia have had in the policy documents was explored by looking at the different definitions that people living with dementia have had during the years. The different goals and rationales that have been part of the narratives on which policies concerning people living with dementia have been based, were also explored. By doing so the field of expertise upon which narratives were based, for example from a medical perspective or from a care perspective, can be identified. How to categorise people living with dementia, for example, in regards to older people, to people with disabilities, people with mental illness and people living with de- 
mentia was also identified. Specific solutions were discerned and also those responsible for them.

Further competing stories that vary from the dominating story were identified. Even though they have not been incorporated into the master narrative they are still there to be identified. Identifying competing stories was important since, according to Miller (2012), Roe, (1994; 1992) and Stone (1989), the policy processes is often occupied by several stories, which strive to influence the specific policy narrative and show the power balance between different stories, those able to influence and those not.

By identifying policy narratives, both the master narrative and competing stories, the patterns that normalise the view of this policy area, that make a coherent whole, were identified. The actors involved in the policy process were also identified since this shows the kind of knowledge base on which the policies rest, which narrative dominates and which actors or network of actors operate within the policy narrative (c.f. Ingram et al., 2014). It is here important to not discern specific actor's ideas, values and beliefs but what they contribute to the construction of the master narrative. It has been important to consider policy narratives as an ongoing construction, fashioned in order to convey a meaning. The episodes, see article I and II, are thus not reflecting a specific policy change or for example the emergence of a competing story, but are rather a way to organise the material.

When analysing the policy documents, it has also been important to not only see what is there but also what is not there. Is the group mentioned at all? Which actors are participating and which are not? Which knowledge and beliefs are not presented? (c.f. Alvesson 2011; Yanow 2000; 1995) Studying, for example which stories, knowledge, values and beliefs are not present in the narrative sheds light on which rationales, knowledge and actors have had the possibility to influence specific policy areas.

\section{Analysing documents through qualitative content analysis}

In addition to a narrative approach, used in Article I, a qualitative content analysis has also been conducted, in Article II (c.f. Bryman, 2012). The focus of the textual analysis was to study how the policy target group of people with dementia had been constructed. The focus of this analysis has been on the semiotics of the policy documents. During this analysis the focus has been on rhetorical signs that provide a certain meaning (c.f. Bryman, 2012; Esaiasson, 2012). Further, the focus has been on the labels, images and definitions of a specific category, which aim at studying the signs indicated by, for example, an individual's, or category of individual's, value or inherent attributes that comes with a specific sign (c.f. Bergström \& Boréus, 2012; Bryman, 2012).

In the analysis of policy documents, after discerning the policy narratives, the analysis was also aimed at investigating the framing of people with dementia during the different time periods. The analysis used in this part of the research is built on the framework offered by Ritche et al. (2003) and Spencer et al. (2003). Even though the analysis has been an iterative process there are a few steps that have been followed. Firstly, the data was managed into themes in which, for example, labels and ascribed attributes were identified. The focus has been on the 
actual labelling and definition that people with dementia have been ascribed in the policy documents, and whether these have changed over time. Further, the attributes that have been ascribed to people with dementia, for example their abilities, their physical and/or psychical conditions were also identified. The data was then classified, managed by assigning the data, by refining categories and themes. By doing this the data was ordered, by refining the categories and themes into positive or negative ascriptions of labels, images and attributes. Furthermore, the occurrences of people with dementia as a group in policy documents was discerned. This ascertains whether they are visible or not or if they belong to other target groups. How specific words are used as connotations and symbols affects the policies created for meeting specific problems. Further possible policies are affected by the meaning ascribed to the words used when making policies (Miller, 2012; Stone, 2012; Bergström \& Boréus, 2012). How certain issues are framed also comes with certain solutions (Stone, 2012). Further, in accordance with Ritche et al. (2003) and Spencer et al. (2003) the analysis also focused on finding underlying meanings (Yanow, 2000; 1995) and developing explanations for the construction of the target group of people with dementia. By studying the rationales that labels, images and ascribed attributes are based upon, the underlying meaning and explanation for how and why specific target groups are constructed was investigated. Finding explanations and underlying meanings also helps in finding applications for theory as well as policy strategies.

\section{Interview study}

In addition to analysing policy documents which have given an insight into the social construction of people with dementia as a policy target group, the aim of this dissertation is also to understand how care managers experience and handle people with dementia when they encounter the welfare system, i.e. the social services. In order to explore and understand the experience of care managers and how they perceive their "reality", interviews with care managers were conducted. Interviews allow us to understand the experiences of people and how they perceive their "reality". Interviews are thus a way to study social phenomena from the perspective of the actors involved in them (Bryman, 2012; Esaiasson et al. 2012). In this study the interviews are used as way of understanding how legislation and policies are used by street-level bureaucrats (Article III) and also the dilemmas they encounter in their work (Article IV)

\section{Selecting municipalities and interviewees}

The interviews were conducted at three municipalities in Sweden. In each municipality we have interviewed actors in different positions in the municipal organisation. The interviewees comprised care managers, mid-level management and politicians.

The selection of municipalities was made quite simplistically by two distinctions, geographical location and size. The aim was to have differences in geographical location from north to south and countryside to inner city in Sweden as 
well as to have differences in size, small cities (under 50000 in population), larger cities (50 000-200 000 in population) and big cities (over 200000 in population) (SALAR, 2010). The selection comprises one smaller municipality located in the south of Sweden, one larger municipality located in the north of Sweden and two districts from a big city in the middle of Sweden. Accordingly, the interviews were made in three municipalities but in four organisations since we chose two districts from one municipality. The selection of municipalities helps us identify experiences on a national basis although the aim is not to compare local variations.

After the selection of municipalities 19 interviewees, care managers, were selected. A key person in each municipality was identified who also functioned as a contact person for us. The contact was made through e-mail and by phone, and meetings with the contact person were scheduled. The contact person was used as a source for information on the organisation and as a way to identify interviewees in the form of care managers. The contact suggested interviewees through a list of potential care managers to interview and a selection from that list was then made. All of the interviewees were contacted by e-mail and telephone. Thus the selection of interviewees was made as a snowball selection (c.f. Bryman 2012; Esaiasson et al. 2012), which means that interviewees who could be of interest to the project were identified with the help of a key person. If the person was willing to be interviewed, a time and a place of their choosing were scheduled for the interview.

The interviews were 19 in total with five interviewees in three of the organisations and four interviewees in one organisation. All of the interviewees were female as all of the candidates provided by us by the contact person were female thus it was not possible to attain gender diversity. The age of the care managers varied from approximately 25 years to 60 years and the range of work experience of the interviewees ranged from approximately one year to 40 years. All of the interviews with care managers were held at their offices. The interviews were conducted by one of the authors of the articles present, with one interviewee at a time. All of the interviewees had been informed beforehand that the interviews would be recorded. They were also informed that the transcripts would be anonymised and that they could end the interview at any time. Even though we could not guarantee the full anonymity of the interviewees there were no interviewees who wanted to stop the interviews when they received this information and they also had an open view within their organisation on participating in the study and for example scheduled appointments for interviews for their colleagues.

\section{Conducting interviews}

Before conducting the interviews, a semi-structured topic guide with open-ended questions was created (c.f. Bryman 2012; Alvesson, 2011). The guide was structured around several topics that we found relevant pertaining to e.g. the organisation, possibility to influence policy, limitations and tricky situations. The interviews followed the approach of "expert interviews" meaning that the interviewees are not interviewed only for their profession but rather considered as experts. This allows the interviewees to choose which topics they want to focus and elab- 
orate on, thus allowing them to converse about what they find interesting. However, these interviewees were selected according to their profession but were not considered as experts in their field. Expert interviews aim at an understanding of the experience and reflections from an interviewee about their everyday practice and practical activities in a certain field (Littig \& Pöchhacker, 2014; Bogner et al., 2009). Follow up questions were prepared beforehand on topics from the topic guide that might not be raised by the interviewees on their own. The follow-up questions also served as clarification of questions the interviewees did not understand. Even if there was an order of topics in the guide there was the flexibility to not follow those topics in a specific order, depending on what the interviewee chose to talk about. The interview guide allowed the interviewee to talk about what they thought relevant at the same time as they did not depart too far from the topic (c.f. Bryman 2012; Alvesson 2011) The guide also developed during the process, as new topics arose when doing the interviews and some themes were added and some were removed from the interview guide. The interview is explained by Kvale \& Brinkmann (2009) as a back and forth process where certain aspects can change during the process e.g. interview-guide, relevant interviewees etc.

\section{Handling the material}

All the interviews were audio recorded. The recordings of the interviews have all been stored on a computer and on two external hard drives. The interviews have been transcribed verbatim into texts and the documents were stored as word files on a computer as well as printed copies of the transcripts have been stored in a locked drawer in my office together with the two external hard drives. The interviews have all been anonymised both on the recordings and in the transcripts and the interviewees have all been given specific codes, and a key for those codes was created in order to keep track of the interviews as well as the interviewees. In the recording, the municipalities to which the interviewees belong to are mentioned, although they have been removed in the transcripts.

\section{Analysing interviews through thematic content analysis}

The analysis of interviews has been made as a thematic content analysis with two approaches, both following the framework of Spencer et al. (2003) and Ritchie et al. (2003). In the first analysis, see Article IV, the texts of the transcribed interviews were read without specific thought of possible interesting themes, but rather the themes arose while doing the analysis. After the first reading the material was categorised into themes. By doing so the data was managed both in terms of its amount and an order was also created. In this step the data was not analysed but only thematically ordered. During this phase the raw material was reduced to a more manageable amount. The material was then read once again to see if there were any occurrences and patterns in those themes that were initially identified. The themes were then coded into more specific themes using Nvivo. The data was then sorted and synthesised according to the themes created in the previous step in order to see specific patterns in the data. A first analysis was made and by 
refining the data, specific elements were identified. A second analysis was made by identifying explanatory accounts. In this analysis questions of why and how were asked, in order to explain why some themes occurred, and in order to attain a meaning for the interviewee's accounts (c.f. Spencer et al., 2003; Ritchie et al., 2003). However, the data analysis was an iterative process, meaning that the steps were ongoing during the whole analytical process and not as easily discerned as in the description, for example by identifying new themes while analysing explanatory accounts. In the last stage we looked for explanations for occurring themes by trying to find the understanding and the meaning given to them by the interviewees. It was also important to try to find underlying meanings (c.f. Yanow, 2000; 1995), thus giving attention to implicit stories from the interviewees, and not only to what can be read in the transcribed texts. In this analysis it was also important to find explanations for how and why questions, as well as seeking applications to theory and policy strategies.

The second approach used, presented in Article III, was more derived from the topic guide. The approach was similar to the first one but differed in the structure of the analysis. This analysis was more derived from the topic guide in which specific topics were analysed. Accordingly, the second analysis was more derived from the theoretical framework than the first analysis. However, once the data management phase was done the data was analysed in a similar manner as explained above. The data was categorised into themes, and specific occurrences and patterns were categorised.

\section{Reflections on method}

In this section the material and the methods used will be discussed. Benefits and issues concerning the data, and the analysis will also be discussed, as well as the quality of the research.

\section{The data}

As mentioned, the data in this dissertation comprises of policy documents and interviews. The policy documents contain a vast source for information and thus the focus has been on national policy documents from public authorities. It could be argued that it would have been beneficial to add documents from other actors such as municipalities and associations, and dementia associations, for example, however this might have proved too wide a scope for this dissertation. Policies from municipalities were discussed with the interviewees so at least a second hand version of policy documents from municipalities is incorporated within this research. It could also be argued that the selection of the time period is arbitrary, however since people with dementia were not mentioned in earlier documents the selection of the starting point as the end of the 1970's became a natural choice.

Concerning the interviews there are also issues that need to be discussed. It could be argued that the interviewees are homogeneous in the sense that they were all female. However, the list of possible interviewees that we were given was female only, and after spending time in the different municipalities this 
proved to be the case concerning care managers. This can perhaps be seen as a critique for the study but may perhaps be considered more of a critique to the municipalities, as this part of their organisation is homogenous concerning gender.

\section{Analysing interviews}

Regarding the conducting and analysing of interviews, there are a few issues that need to be discussed. Firstly, the interviews were conducted by two researchers. This could arguably have affected the interviews if for example different topics were discussed dependent on the differences of the authors' experiences. However, the interviews followed a topic guide which was used during all of the interviews, which not only made sure that the interviewees did not stray too far from the intended topics, but also the interviewers. The topic guide made sure that both interviewers conducted similar interviews, which was also confirmed during the transcription and the analysis of the material. However, by having both authors conducting interviews there was discussion on how to develop the topic guide and also how to pursue interesting accounts, as such the analysis started before all the interviews were completed. Even though the initial analysis, for example managing the data into themes and synthesising the material was carried out by me, the descriptive and explanatory accounts were analysed by both authors. This means that the material had some form of triangulation (c.f. Bryman, 2012; Lincoln \& Guba, 1985) which means that several researchers were involved in the analysis. Triangulation results in material being more thoroughly examined, and it also reduces the risk of arbitrary interpretations of the material since there have been two researchers involved in the analysis process. This adds to the credibility of the study.

\section{A combination of methods}

The combination of methods, even if there was not a combination within one article, have helped to investigate and understand different elements of the policy process. The analysis of policy documents has produced understanding of the rationales, rules, tools, solutions etc. of the policy process while the interviews with care managers has given insight on the implementation part of the policy process, as well as how specific actors, street-level bureaucrats, handle policies in their practice.

However, the study could be strengthened by adding interviews with actors from other levels such as mid-level management and politicians, to see how they experience people with dementia as a target group for social services.

\section{Quality of the research}

When discussing the quality of research it is often considered as having more or less reliability and validity. Qualitative research has often been met with a critique of not being reliable or valid since it lacks systematics, and measurements to validate qualitative research have been attempted as a set of standards for 
evaluating qualitative research. However, qualitative research does have a systematic to it, but just not the same systematics as quantitative research. On the other hand, qualitative research is often cross-disciplinal, varying from a wide range of disciplines such as anthropology, political science and sociology, and qualitative research entails varying methods, e.g. interview studies, observations and document studies (Torrance, 2013; Bryman, 2012; Yanow, 2006). I would therefore like to go beyond the concepts of reliability and validity as a measurement for discussing the quality of my research, since they refer to the fact that a single objective account of a social reality is possible (Bryman, 2012). Guba and Lincoln (1989) and Lincoln and Guba (1985) have suggested alternatives for validity, reliability and objectiveness under the overarching concept of trustworthiness. Trustworthiness incorporates four criteria which are credibility, transferability, dependability and confirmability.

Credibility is concerned with the believability of the research, whether the results are credible. This concerns strategies such as respondent validation, where the interviewees are able to give feedback on the findings. This has not been done in this study. Triangulation is another strategy in which several researchers are a part of the analysis process in order to minimise, for example, arbitrary interpretations of the data (Bryman, 2012). When analysing both the policy documents as well as the interviews, both the authors of the articles were involved. Interesting findings were discussed amongst the authors in order to make sure that the interpretations did not vary from the "realities" presented in the policy documents and the interviews. Drafts of the articles and their findings were also discussed in seminars with fellow researchers adding to the triangulation (Bryman, 2012; Lincoln \& Guba 1985).

Transferability concerns whether the setting in which the study has taken place is relevant to other settings. In order to attain transferability there need to be descriptions of the settings in order to determine if the findings can be applied to other contexts (Bryman, 2012; Lincoln \& Guba 1985). In order to attain transferability there was a description of the setting in which this research took place. It could also be argued that different organisations have different cultural norms and values but the homogeneity in the interviewees answers, even between municipalities, indicates that this research can be transferred to other municipalities. It is also possible that there is transferability to other public organisations in which street-level bureaucrats operate.

Dependability concerns how the researchers have documented the research processes. This includes for example how samples were chosen and how interviewees were contacted (Bryman, 2012; Lincoln \& Guba 1985). The study has been documented by keeping a diary in which the research processes were recorded. This log contains, for example, search words concerning the documents, contacts with key people and dates of the conducted interviews.

Confirmability concerns the bias of the researchers, whether there have been personal values involved in the research which have intruded on the objectiveness of the study (Bryman, 2012; Lincoln \& Guba 1985). The research was conducted at Centre for Dementia Research, at Linköpings University which focuses on people with dementia as actors in our society. However, this research has not 
had an agenda to promote people with dementia as capable actors within society, rather people with dementia have served as a case for studying policy processes within public administration. However, the findings may promote people with dementia as capable actors within society. 


\section{CHAPTER 5: SUMMARY OF ARTI- CLES}

\section{Article I}

Nedlund, A-C \& Nordh, J. (2015). Crafting citizen(ship) for people with dementia: How policy narratives at national level in Sweden informed politics of time from 1975 to 2013. Journal of Aging Studies.

This article explores how policy narratives in national policy documents in Sweden inform associated politics on people living with dementia. This article is based on a textual analysis of policy documents covering nearly 40 years. By analysing how people with dementia have been defined, what the problem formulation and its immanent solutions have been, and how these have differed over time, we have discerned the narratives that informs the policy area of people with dementia. This article sheds light on how policy narratives have shaped the construction of citizens with dementia as policy target groups. This study also shows the temporal character of people living with dementia as a political problem, the implications of policy narratives on people living with dementia as a citizen group, and policy narratives as something being crafted rather than shaped by fixed pre-existing "facts". This article also sheds light on the negative construction of people with dementia, which is based upon dominant narratives which have influenced this policy area. However, dementia, and further, citizens living with dementia, does not have a once and for all stabilised meaning. Instead, the meanings behind the categories continue to evolve and to be crafted, which affects the construction of citizens living with dementia, the space in which to exercise their citizenship and further belonging to the society.

\section{Article II}

Nedlund, A-C \& Nordh, J. (Submitted). Constructing citizenship targets: A matter of labelling, imaging and underlying rationales in the case of people with dementia.

A highly significant element in politics and policies is the process of constructing, categorising and imaging - such as categorising citizens as target groups. In governing document lines and distinctions are drawn to distinguish deserving and undeserving categories of citizens. In these documents government institutionalise and justifies on who are or are not entitled to services. This paper explores the construction of citizenship for people with dementia by analysing how this citizen group has been categorised and imaged in policy documents and the different categories of rationales that lie behind them. The study is based on a qualitative textual analysis of national policy documents in Sweden, covering nearly 40 
years and the study finds that the way people living with dementia have been labelled has differed over time. The study finds that people living with dementia have been situated in various target groups and discourses and that they have been taken care off by the welfare institutions. However, to a large extent the underlying understanding has nevertheless remained persistent where the position of people with dementia has remained weak. The study sheds light on citizenship as something transformative and interrelated that risk to uphold democratic values that delimit the possibility for people with dementia to influence the citizenship. It offers insight into the policy process related to policy change, the social construction of citizens and their connection to multiple underlying rationales. To be involved in the citizenship practice of influencing these rationales, citizens with dementia need to have access to the policy processes in which their citizenship is partly crafted and exercised. This is a matter of belonging to a society.

\section{Article III}

Nordh, J \& Nedlund, A-C. (Submitted). Policy in practice or policy on paper:

Care managers as creative street-level bureaucrats when handling legislation and policies concerning people with dementia.

This articles aims at exploring how care managers in Sweden experience the legislation, policies and guidelines that frame their work. This study is based on 19 interviews with care managers in four different municipal organisations in Sweden.This article shows that care managers need to consider legislation, policies and guidelines from different organisational levels, e.g. national legislation, local policies and guidelines, as well as guidelines from within their organisation, e.g. social care authorities and their own departments. It also shows that legislation, policies and guidelines are vague and unclear This leaves room for interpretation and negotiation rather than providing explicit guidance for care managers. Thus, care managers need to adapt to the situation at hand by creating their own local routines, and this is done by discussing legislation, policies and guidelines in formal as well as informal meetings. This article shows that the care manager's situation is guided by policy in practice rather than policy on paper, that is that care managers create their local routines and their meaning for their work situation. However, it also shows that local routines and procedures must attain coherence over the organisations in order for them to not become arbitrary, thus also unpredictable, for citizens applying for social services. The findings in this article are of importance since it highlights the practical situation that care managers encounter in their work. It also highlights the measurements that care managers take in order to make their work practically feasible. The article also highlights the tension between policy and practice which is of importance for policy makers, care managers as well as citizens encountering the welfare system. 


\section{Article IV}

Nordh, J \& Nedlund, A-C. (2016). To co-ordinate information in practice: Dilemmas and strategies in care management for citizens with dementia. Journal of social services research. 1-17.

This article explores the dilemmas that care managers experience when working with assessments of social services for people living with dementia. It also explores the strategies that care managers use when encountering these dilemmas. The study is based on 19 interviews with care managers in 4 different municipal organisations in Sweden. The study shows that care managers experienced several dilemmas prominently tied to interactional problems concerning the information exchanged between themselves and the person with dementia, as well as refusal from the person with dementia to accept social services. They also experienced conflicting interests between different actors, such as relatives and actors from other professions, involved in the assessments of support for people living with dementia. It was shown that MI (motivational conversations) is a strategy often used by the care managers when handling cases of people living with dementia. Using resources such as relatives and other professionals e.g. medical doctors, occupational therapists and other care managers, was also described as a strategy but could also lead to dilemmas. The study shows that both dilemmas and strategies create moral dilemmas for the care managers concerning participation by, and self-determination of the person with dementia. Decisions on their own situation may be problematic, both in the interaction when people living with dementia have issues in formulating their needs and explaining their situation, as well as being overlooked, by for example relatives, as the decision-maker concerning social services. 


\section{CHAPTER 6: DISCUSSION}

The focus of this dissertation has been to explore the social citizenship for people with dementia. Social citizenship for people with dementia is explored by studying how people with dementia, in policy documents, have been constructed as a target group and also by studying how policies are enacted in practice by care managers, in their work and in their meetings with people with dementia. In this section I will take a social citizenship perspective on these issues. In the following section I will discuss what this means for citizens living with dementia, how they are perceived by society and its implications, their possibility to influence social policy and their possibility to influence their own everyday situation. Further I will discuss how policies and policy practice will affect social citizenship and how people with dementia have served as an interesting case in problematizing social rights and social citizenship.

In order to discuss these issues, I have itemised four points for further discussion: 1) People with dementia as full citizens? 2) People with dementia as stereotyped and stigmatised - A negative construction? 3) Lack of policies and guidelines - Implications for social citizenship? 4) Policies in specific situations - Tensions in care management?

\section{People with dementia as full citizens?}

In Sweden people with dementia have mostly been discussed in relation to health and social care and also regarding their self-determination. This is the case in policy documents (Article I and II) but, to a large extent, also in the public debate (c.f. DN, 130814; 130913; 160804). The fact that people with dementia have been discussed in terms of health and social care is not a new phenomenon, but started in policy documents at the end of the 1970's and this is still occurring today. It seems that the only driving force concerning people with dementia is their care, and to an extent whether they are able to decide on their own care.

This becomes more apparent since Sweden does not have a national strategy for handling people with dementia, not only concerning their care but concerning other issues as well. This can be compared to other Nordic countries, in which Norway was the first to adopt a national strategy concerning people with dementia (Nordens välfärdscenter, 2016). Countries such as the UK (Department of Health, 2009) and several other countries in Europe have also adopted a national strategy for handling people with dementia concerning issues that go beyond that of care, e.g. housing, neighbourhood and issues concerning self-determination.

The absence of a national strategy in Sweden implies that we are missing the larger picture on the issue of people with dementia. Factors outside of care are downplayed, and how people with dementia can function in, for example, their neighbourhood and in society as a whole, is seldom discussed in the public de- 
bate. In the policy narratives there are some competing stories, deviating from the perspective of care although to a small extent. However, these have not gained much attention in the discussion concerning people with dementia (Article I). This can be compared to people with disabilities who have been able to lift their claims onto the agenda and also gained attention regarding their issues, thus society to an extent has been obliged to comply with their claims (c.f. Ministry of Health and Social Affairs, 2011) and concerning this group a more holistic view have been promoted (Barnes, 2007). However, people with dementia are only discussed as claims-making concerning their health and social care and not concerning living in society as a whole and how they could, or should, function in their community. Even in cases of health and social care, the self-determination of people with dementia is questioned concerning their own everyday situation (c.f. DN, 160804; Nedlund \& Taghizadeh Larsson, 2016). People with dementia are given social rights but do not have the possibility, as yet, to influence the policy areas that influence social rights and further social citizenship (c.f. Bellamy, 2001). Sometimes they are considered as not even having the possibility to influence their own everyday situation. Accordingly, the fact that people with dementia have been covered by policies and legislation concerning older people and people with disabilities, also shows that they are overlooked from the point of view of having their own specific situations, which society needs to acknowledge. It can thus be questioned whether people with dementia can be considered as full citizens.

\section{People with dementia as stereotyped and stigmatised - A negative construc- tion?}

The results in this dissertation have shown that the policy target group of people with dementia has been, and still to a large extent is, negatively constructed. They are often depicted as a burden on themselves, on people within their surroundings as well on the state. The policy narrative in public policy documents targeting people with dementia helps to emphasise and cement this construction and even though it is nowadays a little more nuanced, it still negatively constructs people with dementia, both as a target group but also as a social problem and as actors participating in society. Policy narratives help shape and reproduce the construction of policy target groups and social problems linked to these groups, as well as emphasising stereotypical attributes ascribed to target groups (c.f. Stone, 2012; 1989; Schneider \& Ingram, 2005; 1997; Roe, 1994; 1992; Hajer, 1993).

Within the welfare system there is a constantly ongoing discerning of social problems as well as solutions tied to these problems (Qvarsell, 2013). This comes with the marginalisation and de-marginalisation of policy target groups as well as the construction of new ones. Within the welfare system the notion that citizens who are in need of help are supposed to be offered help, in the form of for example social services, is strong. Within the Swedish welfare system, the possibility 
for applying for, being assessed and receiving social services is needs-based which means that the citizens are assessed according to their attributes, capabilities and situation (Rothstein, 2010a). However, the needs that are emphasised within social services often come with a negative construction, that of the citizens inability to secure an income, the citizens inability to take care of themselves and, the citizen's inability to function properly within the society (Jordan, 2003). The citizens who need and want help from the welfare system thus have to comply with the construction of their specific policy target group in order to be granted the help they need.

Within the area of public policies this can be discussed in multiple ways but here I want to highlight two. Firstly, that the discerning of social problems and groups linked to them is negatively constructed is perhaps not astounding. In order to grant categories of citizens help from the welfare system the specific policy target group and their needs must be socially and culturally legitimised (c.f. Stone, 1989). In order to legitimately allocate public resources to a specific policy area, it is perhaps necessary to construct policy target groups as deviant from the "normal" citizens in order to justify why they should receive specific incentives from the welfare system (Schneider \& Ingram, 1997).

However, in order to receive benefits in the form of for example social services, the citizen must comply with the construction of the specific target group, and accordingly comply with a construction of themselves as individuals in order to fit into the target group. However, this helps to reproduce the negative construction of policy target groups, which helps to reproduce the stereotyped category of citizens making them a homogenous group in which individual differences are overlooked. Since policies are often based upon the construction of policy target groups, the incentives created to solve the social problems linked to the specific target group tend to be general and aimed at incorporating all of the citizens that belong to that target group (Wagenaar \& Cook, 2003), for example, older people and people with disabilities. However, the application and assessment of citizen's needs is enacted on an individual basis, which may create a discrepancy between policies, e.g. legislation and guidelines, and the enactment of policies.

Secondly, in order to nuance the construction of people with dementia there has to be a broader spectrum of knowledge on which these constructions are based. The construction of people with dementia in policy documents has been, and to a large extent still is, informed by a medical rationale, but knowledge from other areas needs more influence in the policy process concerning people with dementia in order to nuance the construction of this particular target group, by for example addressing issues other than those concerned with medical assessments. It is even more prominent that people with dementia themselves are not able to make their voices heard. Bellamy (2008; 2001) argues that citizenship is about rights, the entitlement to social services for example, but also about the right to be able to affect the ways that they are formed and implemented. People with 
dementia, as seen in policy documents, are to a large extent either themselves or through advocates, absent from the construction of the target group and the problem formulation, which indicates that they do not have full citizenship. Bellamy (2008; 2001) and Johansson \& Hvinden (2007a; 2007b) argue that citizenship rights are affected by the claims-making and campaigning by citizenship groups, which makes the policy-makers aware of specific problems. However, negative constructions, which in the case of people with dementia, focuses on their disabilities, affect the possibility to gain access to the forums in which the constructions can be changed. Negative construction thus tends to be reproduced. People with dementia and their advocates thus need to be able to be a part of this process in order to influence their construction and further to be able to influence their social citizenship.

Using people with dementia as a label, which in policies, i.e. legislation, are categorised as either older people or people with disabilities, shed light on the discrepancies between policy target groups and individual heterogeneity within these target groups. This becomes apparent by studying the experience of care managers who encounter citizens such as people with dementia, but also how they experience the legislation, policies and guidelines that guide their work.

\section{Lack of policies and guidelines - Implications for social citizenship?}

When it comes to legislation, policies and guidelines there is relatively little governing from national level on how municipalities should organise their social services, for example the type and amount of services. In addition, there is also little guidance for care managers on what social services include within the municipalities (see article III and IV). The result is that care managers, acting as streetlevel bureaucrats, create their own routines within their unit. Accordingly, care managers are significant actors in the shaping of policies and also shape the substantive rights that citizens enjoy. This is even more apparent concerning people with dementia, since they are covered by the legislation concerning older people or people with disabilities.

The basis for a state ruled by law is that citizens should be able to predict the outcome of public decisions. For example, if a citizen is in need of certain social services and fulfils the requirements for a specific incentive they could expect to be granted such. They should also be able to expect a certain amount of that incentive, for example cleaning three times a month, and also some kind of quality of service (Bellamy, 2003). However, when there is little guidance from either national or local level there is a tendency that citizens are not able to gain insight into, or understand, what rights they are entitled to when it comes to social services. Nor can they discuss this amongst their peers since it is not certain that citizens in the same situation receive the same social services. This has practical implications on the predictability of social services for citizens. For people with dementia this is even more apparent since they may be lacking cognitive and communicative functions. The legislation that covers people with dementia is 
prominently covering two other target groups, older people and people with disabilities. Older people, over 65 years old, are covered by the SSA and people with disabilities, under the age of 65, are covered by ASS. This means that people with dementia, depending on their age, are covered by either the SSA or the ASS. However, these legislations do not entitle the same social services in which the SSA is considered stricter than the ASS in what services they offer. This division between individuals due to age makes it perhaps even harder to navigate through the services since people with dementia are covered by both legislations. Depending on their age, two citizens in the same situation may receive different social services and, in prolongation, different citizenship rights.

Since municipalities are highly autonomous in the way they organise their social services there are differences between municipalities as to which social services they can, and will, provide. This is twofold, 1) one could argue that this goes against the belief of universalism, i.e. that citizens should enjoy the same rights. The autonomy of municipalities as well as the discretion of care managers could result in differences between citizens concerning their substantive rights, e.g. the actual social services they are granted. This can be considered as unfair since all citizens should have the same social rights and thus the same social services when their needs are similar to other citizens. However, in Sweden, universalism means that all citizens should have the same possibility to be assessed according to their needs (Rothstein, 2010a). This does not mean that all citizens should enjoy the same type or amount of support since, the assessment of needs is individually based and it is also an interaction and a negotiation between the welfare system, i.e. care managers, and the citizens, for example the applicant and their relatives.

2) In Sweden the municipalities have responsibility for social services. All municipalities due, to for example size and demography do not have the same situation, there might be a large number of older people which means the cost for taking care of them is relatively high compared to a municipality that has a younger population. Thus they may have to reduce the type and amount of support compared to municipalities in different situations. It is also stated in legislation that all citizens in their respective municipality should be treated equally (SFS 1991:900), and thus the emphasis on universalism, in Sweden, is not that pronounced. This implies that citizens in different municipalities may receive different support from the social services and are thus given unequal possibilities to manage their everyday lives. However, the fact that municipalities are responsible for the wellbeing of their citizens, and that social services are managed in the municipalities, may also imply that people with dementia, like any other citizens, are closer to the forums where social services are managed, which may help to influence issues regarding their everyday situation, at least on a local level.

However, the lack of local guidelines, especially targeted at people with dementia, may help emphasise this uncertainty of citizens as to which social services to apply for and which social services to receive. It is not clearly stipulated what for example "a reasonable standard of living" is and not even care managers are certain about what it entails. This makes it even more difficult for citizens to 
foresee which social care they could count on when they are in a situation where they need such.

Seeing people with dementia as a specific target group and also highlighting them in policies, both on paper and in practice, will help to incorporate this group more and provide more guidance for care managers on how to handle this group. Having more specific legislation and policies may also help citizens to be more aware of what they are entitled to, and be more able to predict their substantive rights. Highlighting people with dementia as a specific target may help to more appropriately take care of them in their situation. Although, even by highlighting them, the policies aimed at them may still run the risk of becoming abstract and help to homogenise the target group of people with dementia. However, since all citizens are unique it may still be difficult to incorporate each individual's situation within legislation and policies. More explicit legislation and policies can also affect the care manager's discretion and thus reduce their possibility to find solutions to specific individual's situations, thus creating a more directly controlled organisation concerning social services, which leaves little room for local variations.

\section{Policies in specific situations - Tensions in care-management}

There is also a tension between the legislation and policies, and the practices of the care managers enacting these legislations and policies. As legislation and policies from high-level officials and politicians tend to consider citizens as abstract target groups, they also tend to homogenise these target groups (Stone, 2012; Schneider \& Ingram, 2005; 1997; Wagenaar \& Cook, 2003). However, streetlevel bureaucrats encounter "real" citizens with different situations and different needs (Wagenaar \& Cook, 2003). Accordingly, there is heterogeneity within these abstract and homogenous target groups which surfaces when citizens meet the welfare system. This means that the care managers experience different "realities" than those which are presented in legislation and policies. Schneider \& Ingram (1997) argue that there are often several target groups that are affected by policies aimed at specific target groups. They refer to this as a target chain which means that there is a chain of target groups that are affected by a specific policy. If the target group is far from the intended policy target group, they are less likely to fit the stereotype at which the policy is aimed at. This is apparent in this dissertation, see article III and IV, where people with dementia are covered by the policies aimed at, prominently, older people but also people with disabilities. The policies are not targeting people explicitly but are covered implicitly by legislation and policies aimed at other target groups. The consequence is that this gives care managers few functional guidelines on how to meet and assess the need of social care for people with dementia. Accordingly, people with dementia do not neatly fit the policies by which they are covered and thus not neatly fit the "realities" of the care managers.

The situations that care managers encounter cause certain dilemmas that the care managers have to handle. This is even more apparent concerning people with dementia, since they are not an explicit target group in legislation and policies and are thus covered by legislation and policies not explicitly targeted at 
them. They are thus incorporated within legislation and policies targeted to the target group of older people and people with disabilities which in turn are presented as homogenous. Accordingly, there is little guidance for care managers when dilemmas occur. However, they usually handle these dilemmas, presented in article IV, by finding their own strategies. This implies that care managers have a high level of discretion (Schneider \& Ingram, 1997; Dworkin, 1977) when enacting policies. Accordingly, care managers can be considered as adding values to the policy design (Schneider \& Ingram, 1997), making them influential actors in the policy process. The social care concerning people with dementia is thus highly influenced by policy in practice rather than policy on paper. This also adds to Bellamy's (2008; 2001) argument that citizens can influence policies by bringing cases to the public administration. As care managers have to handle dilemmas concerning people with dementia they have to create routines and procedures and thus they add values to policies (Schneider \& Ingram, 1997). By doing so people with dementia influence policies, at least in practice, but perhaps also by shedding light on the fact that people with dementia, in for example legislation and policies, should be treated as an explicit target group.

Another issue that care managers encounter concerning the tension between policies and the "realities" they face when handling people with dementia, is selfdetermination. Swedish legislation concerning social services emphasises the importance of voluntarism and one's own decision-making concerning one's everyday situation. However, the experience of the care managers in this study shows that people with dementia do not at times have insight into their own illness, or that they do not want to apply for social care for other reasons. This means that the hands of the care managers are tied until they are able to get consent to provide social care for the specific person. Social care in Sweden is also individual which means that certain incentives are tied to a specific person. In a situation where one family member is in need of social care and where this person opposes such the care managers cannot grant social care. However, care managers, in some situations, see that there are citizens that in need of social services, for either the person themselves or their relatives, e.g. spouse, in order to relieve them. Care managers thus have to consider two or perhaps more citizens in some situations where people with dementia are in need of social care. In order to solve these problematic situations, they sometimes find other ways of gaining consent, see article IV, However, this may infringe on the individual's selfdetermination. As shown in article III and IV the care managers do not have support in finding solutions to this dilemma, in legislation and policies, and thus they have to find their own strategies to cope with these types of situations. Should they honour the person's right to self-determination and risk the wellbeing of that person and at times their relatives, or should they circumvent the right to selfdetermination in order to grant the social care they consider the person needs?

Based on the discussion above there is a contribution to be made by problematizing citizenship, legislation and social care policies by using different target groups. By using people with dementia it is shown that this group causes difficulties for actors to adequately handle it. This can be applied to both how to handle them as a policy target group which have been shown by analysing policy 
documents but also in the policy practice when analysing the interviews of care managers.

\section{Future Research}

Hopefully this dissertation has highlighted how people with dementia have been constructed in policy documents and also shed light on the practices in the context of which people with dementia encounter the welfare system. However, there is still more to be studied within this area. Another focus could be to incorporate mid-level management, senior administrators and local politicians in order to cover the whole chain from national policy to the encounter between the welfare system and the citizens. Similar studies can also be carried out with other target groups as their focus. 


\section{REFERENCES}

Alcock, P., \& Ferguson, H. (2012). Social policy and social work. In: Understanding research for social policy and social work, S. Becker, A. Bryman \& H. Ferguson. (Eds). Bristol. The Policy Press.

Alvesson, M. (2011) Interpreting Interviews. London: Sage.

Anderson, B. (2013). Us and them?: The dangerous politics of immigration control. Oxford: Oxford University Press.

Arnold, G. (2014). Policy learning and science policy innovation adoption by streetlevel bureaucrats. Journal of Public Policy. 34 (03), 389 - 414.

Bacchi, C. (2009). Analysing policy: what's the problem represented to be?. Frenchs Forest: Pearson.

Baldwin, C., \& Greason, M. (2016). Micro-citizenship, dementia and long-term care Dementia, 15 (3), 289-303.

Baldwin, Clive. 2008. "Narrative, citizenship and dementia: The personal and the political.” Journal of Aging Studies, 22(3), 222-228.

Baldwin, C., \& Capstick, A. (2007). Tom Kitwood on dementia: A reader and critical commentary. Maidenhead: McGraw-Hill/Open University Press.

Baldwin, M. (2000). Care management and community care: social work discretion and the construction of policy. Aldershot: Ashgate.

Ballenger, J. F. (2006). Self, senility and Alzheimer's disease in modern America. Baltimore: Johns Hopkins University Press.

Bambra, C., Fox, D., \& Scott-Samuel, A. (2005). Towards a politics of health. Health Promotion International. 20 (2), 187-193.

Barbehön, M., Münch, S., \& Lamping, W. (2015). Problem definition and agendasetting in critical perspective. . In: Handbook of Critical Policy Studies. A. Durnová, M. Orsini, F. Fischer, D. Torgersen (Eds). Cheltenham: Edward Elgar Publishing.

Bardach, E. (1977). The implementation game: What happens after a bill becomes a law. Cambridge: MIT Press.

Barnes, C. (2007). Disability activism and the struggle for change disability, policy and politics in the UK. Education, citizenship and social justice, 2(3), 203-221.

Bartlett, R. (2016). Scanning the conceptual horizons of citizenship. Dementia. 15 (3) 453-461.

Bartlett, R., (2014). Citizenship in action: The lived experience of citizens with dementia who campaign for social change. Disability \& Society, 29 (8), 1291-1304.

Bartlett, R., \& O’Connor, D. (2010). Broadening the dementia debate : towards social citizenship. Bristol: Policy.

Bartlett, R. \& O'Connor, D. (2007). From personhood to citizenship: Broadening the lens for dementia practice and research. Journal of Aging Studies. 21, 107-118. 
Behuniak, S.M. (2010). Toward a political model of dementia: Power as compassionate care. Journal of Aging Studies. 24, 231-240.

Behuniak, S. (2011). The living dead? The construction of people with Alzheimer's disease as zombies. Aging and Society. 31 (1), 70-92.

Bellamy, R. (2008). Citizenship: A Very Short Introduction. Oxford: OUP Press.

Bellamy, R. (2003). The Rule of Law. In: Political Concepts. R. Bellamy \& A. Mason (Eds). Manchester: Manchester University Press.

Bellamy, R. (2001). The 'Right to Have Rights': Citizenship Practice and the Political Constitution of the EU. In: Citizenship and governance in the European Union. R. Bellamy. \& A. Warleigh (Eds). London: Continuum.

Bengtsson, H. (2012). Offentlig förvaltning: Att arbeta i demokratins tjänst. Malmö: Gleerups.

Bergström, G., \& Boréus, K. (2012). Textens mening och makt: Metodbok i samhällsvetenskaplig text- och diskursanalys. Lund: Studentlitteratur.

Blumer, H. (1971). Social Problems as Collective Behavior. Social Problems. 18 (3), 298-306.

Bogner, A., Littig, B., \& Menz, W. (2009). Interviewing Experts. London: Palgrave MacMillan.

Boyle, G. (2014). Recognising the agency of people with dementia. Disability \& Society . 29 (7), 1130-1144.

Boyle, G. (2010). Social policy for people with dementia in England: promoting human rights? Health and Social Care in the Community. 18 (5), 511-519.

Boyle G. (2008). The Mental Capacity Act 2005: promoting the citizenship of people with dementia?. Health and Social Care in the Community. 16 (5), 529-537.

Brannelly, T. (2016). Citizenship and people living with dementia: A case for the ethics of care. Dementia. 15 (3) 453-461.

Brannelly, T. (2011a). Sustaining citizenship: People with dementia and the phenomenon of social death. Nursing Ethics. 18 (5), 662-671

Brannelly, T. (2011b). That Others Matter: The Moral Achievement - Care Ethics and Citizenship in Practice with People with Dementia. Ethics and Social Welfare. 5 (2), 210-216.

Brodkin, E.Z. (2015). Street-level organizations and the "real world" of workfare: Lessons from the US. Social Work and Society. 13(1), 1-16

Brodkin, E.Z. (2011). Policy Work: Street-Level Organization under New Managerialism. Journal of Public Administration Research and Theory. 21, 253-277.

Bryman, A. (2012). Social research methods. Oxford: Oxford University Press.

Bytheway, B. (1995). Ageism. Buckingham: Open University Press.

Carrington, K. (2005).Street-level Discretions: Is there a need for control. Public Administration Quarterly. 29 (1/2), 141-162. 
Cedersund, E., \& Olaison, A. (2010). Care management in practice: on the use of talk and text in gerontological social work. International Journal of Social Welfare. 19, 339-347.

Clarke, C., \& Bailey, C. (2016). Narrative citizenship, resilience and inclusion with dementia: On the inside or on the outside of physical and social places. Dementia. 15(3), 434-452.

Clarke, A., Cochrane, A., \& McLaughlin, E. (1994). Introduction. In: Managing Social Policy. A. Clarke, A. Cochrane \& E. McLaughlin. (Eds). London: Sage.

Colebatch, H.K., Hoppe, R., \& Noordegraaf, M. (2010). Understanding Policy Work. In: Working for Policy. H.K. Colebatch, Hoppe, R. \& Noordegraaf, M. (Eds). Amsterdam: Amsterdam Press.

Colebatch, H.K. (2009). Policy. ( $2^{\text {nd }}$ ed). Buckingham: Open University Press.

Colebatch, H.K. (2002). Government and Governmentality: Using Multiple Approaches to the Analysis of Government. Australian Journal of Political Science. 37 (3), 417-435.

Considine, M. (2005). Making Public Policy: Institutions, Actors, Strategies. Cambridge: Polity Press.

Craft, J. (2015). Conceptualizing the policy work of partisan advisers Policy Science. 48, 135-158.

Craig, G. (2004). Citizenship, Exclusion and Older People. Journal of Social Policy. 33 (1), 95-114.

Cruikshank, B. (1999). The will to empower: Democratic citizens and other subjects. London: Cornell University Press.

Dagens Nyheter. (2013). Otydliga regler tvingar vårdpersonal bli lagbrytare. 14 augusti.

Dagens Nyheter (2013). Unga anhöriga får lite stöd. 13 september.

Dagens Nyheter. (2016). När minnet sviker oss. 4 augusti.

Dahl, R. A. (1989). Democracy and its Critics. Yale University Press.

Daly, M. (2011). Welfare. Cambridge: Polity Press.

Department of Health. (2009). Living well with dementia: A National Dementia Strategy. London: Department of Health.

Dominelli, L., \& Moosa- Mitha, M. (2014). Introduction. In: Contemporary Social Work Studies : Reconfiguring Citizenship : Social Exclusion and Diversity within Inclusive Citizenship Practices. L. Dominelli \& M. Moosa-Mitha. (Eds). Surrey: Ashgate.

Downs, M. (1997). The emergence of the person in dementia research. Ageing and Society, 17(5), 597-607.

Drury, I. (2014). Performance Management for Wicked Problems: Reflections from Child Welfare’s Front Line. Administrative Theory \& Praxis. 36, (3), 398-411.

Dunér, A., \& Wolmesjö, M. (2015). Interprofessional collaboration in Swedish health and social care from a care manager's perspective. European Journal of Social Work, 18:3, 354-369. 
Dunér, A., \& Nordström, M. (2005). Biståndshandläggningens villkor och dilemman inom äldre och handikappomsorgen. Lund: Studentlitteratur.

Durose, C. (2011). Revisiting Lipsky: Front-Line Work in UK Local Governance. Political Studies. 59, 978-995.

Dwyer, P. (2010). Understanding social citizenship: Themes and perspectives for policy and practice $\left(2^{\text {nd }}\right.$ ed). Bristol: The Policy Press.

Dworkin, R. (1977). Taking Rights Seriously. London: Ducksworth.

Ellis, K. (2014). Professional Discretion and Adult Social Work: Exploring Its Nature and Scope on the Front Line of Personalisation. British Journal of Social Work. 44, 2272-2289.

Ellis, K. (2011). Street-level Bureaucracy’ Revisited: The Changing Face of Frontline Discretion in Adult Social Care in England. Social Policy \& Administration. 45, (3), 221-244.

Elmér, Å., Blomberg, S., Harrysson, L., \& Petersson, J. (2000). Svensk socialpolitik. Studentlitteratur.

Esaiasson, Peter., Gilljam, Mikael., Oscarsson, Henrik., \& Wängnerud, Lena. (2012). Metodpraktikan - Konsten att studera samhälle, individ och marknad (4. uppl.). Stockholm: Norstedts Juridik AB.

Erlingsson, G., \& Wänström, J. (2015). Politik och förvaltning i svenska kommuner. Lund: Studentlitteratur.

Fainstein, S. (2015). Social justice and urban policy deliberation: balancing the discourses of democracy, diversity and equity. In: Handbook of Critical Policy Studies. A. Durnová, M. Orsini, F. Fischer, D. Torgersen. (Eds). Cheltenham: Edward Elgar Publishing.

Feldman, R., \& Singer, J. (2007). The Text Mining Handbook: Advanced Approaches in Analyzing Unstructured Data. Cambridge: Cambridge University Press.

Fischer, F., Torgersen, D., Durnová, A \& Orsini, M. (2015). Introduction to critical policy studies. In: Handbook of Critical Policy Studies. A. Durnová, M. Orsini, F. Fischer, D. Torgersen. (Eds).. Cheltenham: Edward Elgar Publishing.

Fischer, F. (1993). Citizen participation and the democratization of policy expertise: From theoretical inquiry to practical cases. Policy Science, 26, 165-187.

Forsell, E., Torres, S., \& Olaisson, A. (2013). Care managers' experience of crosscultural needs assessment meetings: the case of late-in-life immigrants. Aging \& Society. 35, 576-601.

Forsell, E., \& Torres, S. (2012). Social work, older people and migration: An overview of the situation in Sweden. European Journal of Social Work. 15, 115-130.

Galpin, D. (2010). Policy and the protection of older people from abuse. Journal of Social Welfare \& Family Law, 32 (3), 247-255.

Gilmour, J. A., \& Brannelly, T. (2009). Representations of people with dementia- subaltern, person, citizen. Nursing Inquiry. Vol 17 (3), 240-247.

Gofen, A. (2013). Mind the Gap: Dimensions and Influence of Street-Level Divergence. Journal of Public Administration Research and Theory. 24, 473-493. 
Guba, E. G., \& Lincoln, Y.S. (1989). Fourth generation evaluation. New York: Sage.

Gubrium, J. F., \& Holstein, J.A. (1998). Narrative Practice and the Coherence of Personal. Stories The Sociological Quarterly. 39 (1), 163-187.

Hajer, Maarten. 1993. Discourse Coalitions and the Institutionalization of Practice: The case of Acid Rain in Britain. In: The Argumentative Turn in Policy Analysis and Planning. F, Fischer. \& J, Forester. (Eds). Durham: Duke University Press.

Heinrich, S., Laporte Uribe, F., Roes, M., Hoffmann, W., Thyrian, J.R., WolfOstemann, K., \& Holle, B. (2016). Knowledge management in dementia care networks: a qualitative analysis of successful information and support strategies for people with dementia living at home and their family caregivers. Public Health. 131, 40- 48.

Heclo, H. (1994). Ideas, interests, and institutions. The dynamics of American politics: Approaches and interpretations, 366-392.

Hellström, I., Eriksson, H., \& Sandberg, J. (2015). Chores and sense of self: gendered understandings of voices of older married women with dementia. International Journal of Older People Nursing, 10,( 2), 127-135.

Hellström, I. \& Torres, S. (2013) A wish to know but not always tell - couples living with dementia talk about disclosure preferences. Aging \& Mental Health. 17(2): 157-167.

Howlett, M. (2015). Policy analytical capacity: The supply and demand for policy analysis in government. Policy \& Society. 34, 173-182.

Howlett, M. (2014). From the "old” to the” new” policy design: Design thinking beyond markets and collaborative governance. Policy Science. 47, 187-207.

Hunter, C., \& Doyle, C. (2014). Dementia Policy in Australia and the 'Social Construction' of Infirm Old Age. Health \& History: Journal of the Australian \& New Zealand Society for the History of Medicine. 16 (2), p44-62.

Hydén, L-C., \& Hellström, I. (2016). Att leva med demens. Malmö: Gleerups.

Hydén, L-C. (2014). Cutting Brussels sprouts: Collaboration involving persons with dementia. Journal of Aging Studies. 29,115-123.

Hydén, L-C., \& Nilsson, E. (2013). Couples with dementia: Positioning the 'we'. Dementia. 14 (6), 716-733.

Ingram, M., Ingram, H., \& Lejano, R. (2014) What's the story? Creating and sustaining environmental networks, Environmental Politics, 23 (6), 984-1002,

Isin, E., \& Turner, B. S. (2007). Investigating Citizenship: An Agenda for Citizenship Studies. Citizenship Studies, 11 (1), 5-17

Isin , E., \& Wood, P.K.(1999). Citizenship \& Identity. London: SAGE.

Janlöv, A.-C., Rahm Hallberg, I.-L., \& Petersson, K. (2011). Care managers’ view of family influence on needs assessment of older people. Scandinavian Journal of Caring Sciences, 25(2), 243-252.

Johansson, H., \& Hvinden, B. (2007a). Opening citizenship: why do we need a new understanding of social citizenship?. In: Citizenship in Nordic welfare states - Dy- 
namics of choice, duties and participation in a changing Europe.. B. Hvinden \& H. Johansson. (Eds). London: Routledge.

Johansson, H., \& Hvinden, B. (2007b). What do we mean by active citizenship?. In: Citizenship in Nordic welfare states - Dynamics of choice, duties and participation in a changing Europe. (Eds). B. Hvinden \& H. Johansson. London: Routledge.

Jordan, B. (2003). Welfare and social exclusion. In: Political Concepts. R. Bellamy \& A. Mason (Eds). Manchester: Manchester University Press.

Jönson, H. (2009). Äldreomsorgen, ålderismen och de nästan döda. in: Åldrande, åldersordning, ålderism. H. Jönson (ed). Linköping: LiU-Tryck.

Jönson, H. (2002). Ålderdom som samhällsproblem. Lund: Studentlitteratur.

Keiser, L. R. (2001). Street-level bureaucrats, administrative power and the manipulation of federal social security disability programs. State Politics \& Policy Quarterly, 1(2), 144-164.

Kelly, F., \& Innes, A. (2013). Human rights, citizenship and dementia care nursing. International Journal of Older People Nursing. 8 (1), 61-70.

Kitwood, T. (1997). Dementia reconsidered: The person comes first. Buckingham: Open University Press.

Kjaer, A.M. (2004). Governance. Cambridge: Polity Press.

Kvale, S \& Brinkmann, S. (2009). Den kvalitativa forskningsintervjun. Lund: Studentlitteratur.

Kvist, J., Fritzell, J., Hvinden, B., \& Kangas, O. (2012). Changing social inequality and the Nordic welfare model. In: Changing social inequality - The Nordic welfare model in the $21^{\text {st }}$ century. J. Kvist, J. Fritzell, B. Hvinden \& O. Kangas. Bristol: The policy press.

Lasswell, H. (1936). Politics: Who Gets What, When, How. Gloucester: Peter Smith Inc.

Laybourne A.H., Jepson, M.J., Williamsson, T., Robotham, D., Cyhlarova, E., \& Williams, V. (2016). Beginning to explore the experience of managing a direct payment for someone with dementia: The perspectives of suitable people and adult social care practitioners. Dementia. 15 (1) 125-140.

Levin, P. (1997).Making Social Policy. Buckingham: Open University Press.

Lewis, J. (2012). Documents in qualitative research. . In: Understanding research for social policy and social work, S. Becker, A. Bryman \& H. Ferguson. (Eds). Bristol. The Policy Press.

Lincoln, Y.S., \& Guba, E.G. (1985). Naturalistic inquiry. New York: Sage.

Lindelöf, M., \& Rönnbäck, E. (2007). Biståndshandläggning och handlingsutrymme: från ansökan till beslut i äldreomsorgen. Lund: Studentlitteratur.

Lipsky, M. (1980). Street-level bureaucrats: dilemmas of the individual in public services. New York: Russel Sage foundation.

Lister, R. (2003). Citizenship - Feminist Perspectives (2 ed). New York: Palgrave Macmillan. 
Littig, B., \& Pöchhacker, F. (2014). Socio-Translational Collaboration in Qualitative Inquiry: The Case of Expert Interviews. Qualitative Inquiry. 20 (9), 1085-1195

Lundquist, L. (2010). Etik I offentlig förvaltning. In: Politik som organisation: förvaltningspolitikens grundproblem (4th ed). B. Rothstein (Ed). Stockholm: SNS förlag.

Lundquist, L. (1998). Demokratins väktare: Ämbetsmännen och vårt offentliga etos. Lund: Studentlitteratur.

Marcusson, J., Blennow, K., Skoog, I., \& Wallin, A. (2011). Alzheimers sjukdom och andra kognintiva sjukdomar. Stockholm: Liber.

Marshall, T.H. (1950). Citizenship and social class. Cambridge: University of Cambridge Press

Matthews, E. (2006). Dementia and the identity of the person. in: Dementia : Mind, Meaning, and the Person. J. C. Hughes, S. J. Louw and S. Sabat (Eds). Oxford: Oxford University Press.

Maynard-Moody, S., \& Musheno, M. (2012). Social Equities and Inequities in Practice: Street-Level Workers as Agents and Pragmatists. Public Administration Review. 72 (S1), S16-S23.

Maynard-Moody, S., \& Musheno, M. (2000). State Agent or Citizen Agent: Two Narratives of Discretion. Journal of Public Administration Research and Theory. 10 (2), 329-358.

McEldowney, R., \& Teaster, P. B. (2009). Land of the Free, Home of the Brave: Voting Accomodations for Older Adults. Journal of Aging \& Social Policy. 21, 159-171

Miller. H.T. (2012).Governing Narratives: Symbolic Politics and Policy Change. Alabama: The University of Alabama Press.

Ministry of Health and Social Affairs. (2011) En strategi för genomförande av funktionshinderspolitiken 2011-2016. Stockholm: Government Offices.

Montin, S., \& Granberg, M. (2013). Moderna kommuner. Stockholm: Liber.

Nedlund, A-C., \& Taghizadeh Larsson, A. (2016). To protect and to support: How citizenship and self-determination are legally constructed and managed in practice for people living with dementia in Sweden. Dementia. 15(3), 343-357.

Nedlund, A., Jansson, M., \& Nordh, J. (2016). Medborgare med demenssjukdom. In: L-C. Hydén \& I. Hellström (Eds.), Att leva med demens. Malmö: Gleerups

Nedlund, A-C. (2012). Designing for Legitimacy - Policy Work and the Art of Juggling When Setting Limits in Health Care. Linköping: LiU-Tryck

Nelson, T. D. (2002). Ageism: stereotyping and prejudice against older persons. Cambridge: MIT Press.

Nordens Välfärdscenter Sverige. (2016). Demens - möjligheter till livskvalitet. Stockholm: Nordens välfärdscenter.

O’Connor, D., Phinney, A., Smith, A., Small, J., Purves, B., Perry, J., Drance, E., Donnelly, M., Chaudhury, H., \& Beattie, L. (2007). Personhood in dementia care: developing a research agenda for broadening the vision. Dementia International Journal of Social Research and Practice, 6(1), 121-142. 
Olaison, A., \& Cedersund, E. (2008). Home care as a family matter? Discursive positioning, storylines and decision-making in assessment talk. Communication \& Medicine, An Interdisciplinary Journal of Healthcare, Ethics \& Society. 5, 145158.

Olaison, A., \& Cedersund, E. (2006). Assessment for home care: Negotiating solutions for individual needs .Journal of Aging Studies. 20, 367-380.

Oliver, M., Sapey, B., \& Thomas, P. (2012). Social work with disabled people. New York. Palgrave MacMillan

Oliver, M. (2009). Understanding disability: from theory to practice. New York: Palgrave.

Phoenix, C., Smith, B., \& Sparkes, A. C. (2010). Narrative analysis in aging studies: A typology for consideration. Journal of Aging Studies. 24, 1-11.

Plejert, C., Jansson, G., \& Yazdanpanah, M. (2014). Response Practices in Multilingual Interaction with an Older Persian Woman in a Swedish Residential Home. Journal of Cross-Cultural Gerontology. 29, 1-23.

Postle, K. (2002). Working 'between the idea and the reality': Ambiguities and tensions in care managers' work. British Journal of Social Work, 32(3), 335-351.

Pressman, J., \& Wildavsky, A. (1973/1984). Implementation: How Great Expectations in Washington are Dashed in Oakland; or, Why It's Amazing that Federal Programs Work at all, This Being a Saga of the Economic Development Administration as Told by Two Sympathetic Observers Who Seek to Build Morals on a Foundation of Ruined Hopes. Berkeley: University of California Press.

Priestley, M. (2003). Disability: A life course approach. Cambridge: Polity.

Qvarsell, R. (2013). Välfärdssamhällets idémässiga historia. In: Vägar till välfärd idéer, inspiratörer, kontroverser, perspektiv. H. Swärd, P.G. Edebalk \& E. Wadensjö. (Eds). Stockholm: Liber.

Rauch, D. (2008). Central versus Local Service Regulation: Accounting for Diverging Old-age Care Developments in Sweden and Denmark, 1980-2000.Social Policy \& Administration, 42(3), 267-287.

Rein, M., \& Schön, D. (1996). Frame-Critical Policy Analysis and Frame-Reflective Policy Practice. Knowledge and Policy: The International Journal of Knowledge Transfer and Utilization. 9 (1), 85-104.

Ritchie, J., Spencer, L., \& O’Connor, W. (2003). Carrying out Qualitative Analysis. In: Qualitative Research Practice: A Guide for Social Science Student and Researchers. J. Ritchie \& J. Lewis. (Eds). London: Sage.

Rodger, J. J. (2000). From a welfare state to a welfare society: the changing context of social policy in a postmodern era. London: MacMillan Press Ltd

Roe, E. M. (1992). Applied narrative analysis: The tangency of literary criticism, social science and policy analysis. New Literary History, 23(3), 555-581.

Roe, E. M. (1994). Narrative policy analysis: Theory and practice. Durham: Duke University Press.

Rothstein. B. (2010a). Vad bör staten göra: Om välfärdsstatens moraliska och politiska logik. Stockholm: SNS Förlag 
Rothstein, B. (2010b). Välfärdsstat, förvaltning och legitimitet. In: Politik som organisation: förvaltningspolitikens grundproblem (4th ed). B. Rothstein (Ed). Stockholm: SNS förlag.

Sabatier, P., \& Mazmanian, D. (1979). The conditions of effective implementation: A guide to accomplishing policy objectives. Policy analysis, 481-504.

Schlager, E., \& Weible, C.M. (2013). New Theories of the Policy Process. The Policy Studies Journal. 41 (3), 389-396.

Schierup, C., Hansen, P., \& Castles, S. (2006). Migration, Citizenship, and the European Welfare State: A European Dilemma. Oxford: Oxford University Press.

Schneider, A., Ingram, H., \& deLeon, P. (2014). Social construction of target populations. In: Theories of the policy process. P. A. Sabatier, \& C. M. Weible (Eds.) Boulder: Westview Press.

Schneider, A., \& Ingram, H. (Eds.). (2005). Deserving and entitled: Social constructions and public policy. Albany: State University of New York Press.

Schneider, A., \& Ingram, H. 1997. Policy design for democracy. Kansas: University Press of Kansas.

Schneider, A., \& Ingram. (1993). Social Construction of Target Populations: Implications for Politics and Policy. American Political Science Review 87(2): 334-347.

Schneider, A., \& Sidney, M. (2009). What Is Next for Policy Design and Social Construction Theory. The policies Studies Journal. 37 (1), 103-109.

Scourfield, P. (2015). Even Further beyond Street-Level Bureaucracy: The Dispersal of Discretion Exercised in Decisions Made in Older People's Care Home Reviews. British Journal of Social Work. 45, 914-931.

SFS 2001:453. Socialtjänstlagen [Social Services Act]. Stockholm: Swedish Code of Statutes.

SFS 1993:387. Lagen om stöd och service för vissa funktionshindrade [The Swedish Act concerning Support and Service for Persons with Certain Functional Impairments]. Stockholm: Swedish Code of Statutes.

SFS 1991:900. Kommunallag. [The Local Government Act]. Stockholm: Swedish Code of Statutes.

SFS 1986:223. Förvaltningslag [The Administrative Procedure Act]. Stockholm: Swedish Code of Statutes.

SFS 1982:763. Hälso- och sjukvårdslagen. [Health and Medical Services Act]. Stockholm: Swedish Code of Statutes.

SFS 1974:109. Regeringsformen. [Instrument of Government]. Stockholm: Swedish Code of Statutes.

Shanahan, E. A., Jones, M. D., McBeth, M. K., \& Lane, R. R. (2013). An Angel on the Wind: How Heroic Policy Narratives Shape Policy Realities. The Policy Studies Journal. 41 (3), 453-483.

Socialstyrelsen [NBHW]. (2014a). Demenssjukdomarnas samhällskostnader i Sverige 2012. Art nr: 2014-6-3. 
Socialstyrelsen [NBHW]. (2014b). Öppna jämförelser 2014: Cancersjukvård jämförelser mellan landsting. Art nr: 2014-12-2, ISBN 978-91-7555-222.

Sonnicksen, J. (2016). Dementia and representative democracy: Exploring challenges and implications for democratic citizenship. Dementia. 15(3) 330-342.

Soss, J. (2005). Making Clients and Citizens: Welfare Policy as a Source of Status, Belief and Action. In: Deserving and entitled: Social constructions and public policy.A. Schneider \& H. Ingram. (Eds). Albany: State University of New York Press.

Soss, J., Fording, R. C., \& Schram, S. F. (2011). Disciplining the Poor: Neoliberal Paternalism and the Persistent Power of Race. Chicago: University of Chicago Press.

Spector, M., \& Kitsuse, J. I. (1973). Social problems: A re-formulation. Social problems, 21(2), 145-159.

Spencer, L., Ritchie, J., \& O’Connor. (2003). Analysis: Practices, Principles and Processes. In: Qualitative Research Practice: A Guide for Social Science Student and Researchers. J. Ritchie \& J. Lewis. (Eds). London: Sage

Stone, D. A. (2012). Policy Paradox: The Art of Political Decision Making ( $3^{\text {rd }}$ ed). New York: W.W Norton \& Company Inc.

Stone, D. A. (1989). Causal stories and the formation of policy agenda. Political Science Quarterly, 104(2), 281-300.

Stone, D. A. (1984). The Disabled State. Philadelphia: Temple University Press

Sveriges Kommuner och Landsting [SALAR]. (2010). Kommungruppsindelning 2011 REVIDERING AV SVERIGES KOMMUNER OCH LANDSTINGS KOMMUNGRUPPSINDELNING. ISBN 978-91-7164-585-2

Swärd, H. (2013). Det tudelade välfärdssystemet. In: Vägar till välfärd - idéer, inspiratörer, kontroverser, perspektiv. H. Swärd, P.G. Edebalk \& E. Wadensjö. Stockholm: Liber.

Szebehely, M. (2011). Insaster för äldre och funktionshindrade i privat regi. In Hartman, Laura. (Ed). Konkurrensens konsekvenser. Vad händer med svensk välfärd?. Stockholm: SNS förlag.

Taylor-Gooby, P. (2008). Reframing social citizenship. Oxford: Oxford University Press.

Tiraboschi. P., Chitó, E., Sacco, L., Sala, M., Stefanini, S., \& Defantil, C.A. (2011). Evaluating Voting Competence in Persons with Alzheimer Disease. International Journal of Alzheimer's Disease. 2011, 1-6.

Torgersen, D. (2015). Harold D. Lasswell and critical policy studies: the threats and temptations of power. In: Handbook of Critical Policy Studies. A. Durnová, M. Orsini, F. Fischer, \& D. Torgersen. (Eds). Cheltenham: Edward Elgar Publishing.

Torrance, H. (2013). Qualitative Research, Science and Government - Evicence, Criteria, policy and Politics. In: Collecting and Interpreting Qualitative Materials, N. K. Denzin \& Y. S. Lincoln. (Eds). Thousand Oaks: Sage.

Trydegårdh, G-B. (2013). Från fattigvård till kundval - den svenska äldreomsrogens framväxt. In: Vägar till välfärd - idéer, inspiratörer, kontroverser, perspektiv. H. Swärd, P.G. Edebalk \& E. Wadensjö. Stockholm: Liber. 
Trydegårdh, G-B., \& Thorslund, M. (2010). One Uniform Welfare state or a Multitude of Welfare Municipalities? The evolution of Local Variation in Swedish Elderly Care. Social Policy \& Administration, 44 (4), 495-311.

Tummers, L., \& Bekkers, V. (2014). Policy implementation, street-level bureaucracy, and the importance of discretion. Public Management Review, 16 (4), 527-547.

Turnbull, N. (2013). The questioning theory of policy practice: outline of an integrated analytical framework. Critical Policy Studies.

DOI:10.1080/19460171.2013.776501

Turner, B. S. (2001). The erosion of citizenship. British Journal of Sociology. 52 (2), 189-209

Van Kersbergen, K., \& Vis, B. (2014). Comparative Welfare State Politics: Development, Opportunities and Reform. Cambridge: Cambridge University Press.

Van Meter, D. S., \& Van Horn, C. E. (1975). The policy implementation process a conceptual framework. Administration \& Society, 6(4), 445-488.

Wagenaar, H., \& Cook, S.D. (2003). Understanding policy practices: action, dialectic and deliberation in policy analysis. In: Deliberative Policy Analysis: Understanding Governance in the Network Society. M. A. Hajer \& H. Wagenaar. (Eds). Cambridge: Cambridge University Press

Weible, C.M. (2008). Expert-Based Information and Policy Subsystems: A Review and Synthesis. The Policy Studies Journal. 36 (4), 615-635.

Yanow, D. (2015). Making sense of policy practices: interpretation and meaning. In: Handbook of Critical Policy Studies. A. Durnová, M. Orsini, F. Fischer, D. Torgersen. (Eds). Cheltenham: Edward Elgar Publishing.

Yanow, D. (2006). Neither Rigorous nor objective? Interrogating Criteria for Knowledge Claims in Interpretative Science. In: Interpretation and Method Empirical Research Methods and the Interpretative Turn. D. Yanow \& P. Schwartz-Shea (Eds),. New York: M.E.Sharpe

Yanow, D. (2000). Conducting interpretive policy analysis. London: SAGE.

Yanow, D. (1995). Built space as story: The policy stories that buildings tell. Policy Studies Journal, 23(3), 407-422.

Yuval-Davis, N. (2011). The politics of belonging: Intersectional contestations. Los Angeles, Calif.: Sage.

Örulv, L. (2012). Refraiming dementia in Swedish self-help group conversations: Constructing citizenship. The International Journal of Self-help and Self-care. 6 (1), 9-41.

Österholm, J. (2016). Assessment meetings between care managers and person living with dementia: Citizenship as practice. Linköping: LiU-Tryck.

Österholm, J., Taghizadeh Larsson, A., \& Olaison, A. (2015). Handling the dilemma of self-determination and dementia: A study of case managers' discursive strategies in assessment meetings. Journal of Gerontological Social Work. 58 (6), 613-36.

Österholm, J., \& Samuelsson, C. (2015). Orally positioning people with dementia in assessment meetings. Ageing and Society. 35 (2), 367-388. 
Österholm, J., \& Hydén, L-C. (2014). Citizenship as practice: Handling communication problems in encounters between persons with dementia and social workers. Dementia. 0 (0), 1-17. 


\section{Topic Guide: Care managers}

\section{Role and responsibilities}

- Role

- Responsibilities

- Work tasks

\section{Organisational Map}

- Departments handling issues of elderly care and people with dementia

- Political boards

- Responsibilities

- Cooperation - Coordination

\section{National Guidance}

- National Goals, - Regulations - Legislation - Guidelines - Incentives

- Possibility to influence - Directly/Indirectly

\section{Municipal/local policies concerning people with dementia}

- Formally - Organisation - Structure

- Formally - Goals - Policies - Guidelines - Written routines - Meetings

- Informally - Meetings - Discussions - In the corridor

- Clashes between national and local

\section{Services for people with dementia}

- Goals concerning care and services for people with dementia - Several goals

- Conflicting goals

- How are they developed

- Actors involved - Actors missing

- Possibility to meet goals

\section{Working procedures}

- Specific working procedures when assessing and deciding on social services

- Meetings - Where - Follow ups

- Order in services granted

\section{Handling tricky situations?}

- Examples of tricky situations

- Handling tricky situations

- Discussions - Meetings - Actors involved - Collectively

- Concerning legislation, policies and guidelines 
Limitations on how policies are practiced and shaped

- Economic - Demographic - Geographic - Policies

- Other examples

\section{Professional discretion}

- Possibility to handle work tasks

- Economy/Services

- Freedom of choice/Services

- Reactions from public officials

- Change in policies

\section{Reactions}

- Reactions from actors

- People with dementia

- Public officials

- Relatives

- Positive/Negative

- Critique - Which forums

- Elderly council - Reference groups

- Other actors - Media - Interest groups

\section{Municipalities handling reactions}

- Developing policies

- More and better information

\section{Private/Municipal regimes}

- Differences

- Fulfilling responsibilities

- Adjusting to rules and responsibilities

- Relatives as deliverers of service

\section{County councils/Regions}

- Cooperation

- Coordination

\section{Closure}

- Anything else? 


\section{Articles}

The articles associated with this thesis have been removed for copyright reasons. For more details about these see:

http://urn.kb.se/resolve?urn=urn:nbn:se:liu:diva-131477 